\title{
Review \\ Clays and Clay Minerals in the Construction Industry
}

\author{
Nakshatra Bahadur Singh
}

check for

updates

Citation: Singh, N.B. Clays and Clay Minerals in the Construction

Industry. Minerals 2022, 12, 301.

https://doi.org/10.3390/

$\min 12030301$

Academic Editors: Fernando Rocha and Mazen Alshaaer

Received: 17 January 2022

Accepted: 25 February 2022

Published: 27 February 2022

Publisher's Note: MDPI stays neutral with regard to jurisdictional claims in published maps and institutional affiliations.

Copyright: (C) 2022 by the author. Licensee MDPI, Basel, Switzerland. This article is an open access article distributed under the terms and conditions of the Creative Commons Attribution (CC BY) license (https:// creativecommons.org/licenses/by/ $4.0 /)$.
Department of Chemistry and Biochemistry and Research Development Cell, Sharda University, Greater Noida 201306, India; n.b.singh@sharda.ac.in

\begin{abstract}
Clay is a naturally occurring material that can be converted to different clay minerals through thermal treatments, and can be used for the development of different products. Clays and clay minerals have been used for different applications in different sectors. Detailed information regarding the applications of these materials in the construction industry are described. Clay has been used as a supplementary cementitious material in Portland cement (OPC) mortars and concretes. These minerals decrease raw materials and $\mathrm{CO}_{2}$ emissions during the production of Portland cement clinker and, at the same time, increase the compressive strength of concrete at a later age. Therefore, they are conducive to the sustainability of construction materials. A new type of cement, Limestone calcined clay cement $\left(\mathrm{LC}^{3}\right)$, and a binding material geopolymer cement have also been developed using clay minerals. The properties of these binders have been discussed. Applications of clay products for making bricks have are also described in this article.
\end{abstract}

Keywords: clay; mineral; cement; concrete; geopolymer; construction; LC ${ }^{3}$

\section{Introduction}

Construction is one of the most important and oldest industries in the world. It is as old as civilization. Nowadays, the construction industry is the leading industry in all market economies. The construction industry uses a variety of materials such as cement, concrete, aggregates, clay, wood, metals, and bricks. The choice of these materials depends on their properties and cost. Out of different construction materials, binders are the most used materials in the construction industry. One of the most important binders is cement and concrete. Portland cement (OPC) is the main binder, with different constituents and compositions. The manufacture of OPC consumes a lot of energy and raw materials, and at the same time emits about $7 \%$ of the $\mathrm{CO}_{2}$ gas responsible for global warming. Nowadays, a lot of supplementary cementitious materials (SCMs) (industrial and agricultural wastes) are being used as a partial replacement of OPC clinker. Because of the limited availability of SCMs, they cannot be considered a global alternative for substitution in cement $[1,2]$. Recently, attempts have been made to replace the waste materials (SCMs) from naturally occurring materials like clay, which contains lot of alumina and silica, as such clays can cause a pozzolanic reaction under the proper conditions. Clays are found in abundance in almost all countries $[1,3]$.

Calcined clay (CC) is considered to be an important pozzolanic material [4,5] because kaolinitic clays are found in abundance worldwide, showing the potential to work as SCMs. Compared to fly ash and slag, CC does not have a variable chemical composition and hence the properties of clay blended cements are more controllable and predictable. The use of CC has been studied in conventional OPC systems, as well as in limestone calcined clay cement $\left(\mathrm{LC}^{3}\right)$ and CC-based geopolymer systems [6-8]. In CC blended cement, the maximum replacement of OPC by CC is 30\% [9], whereas in an $\mathrm{LC}^{3}$ system, the level of substitution could reach 50\% [9]. The CC-based geopolymer may be substituted with OPC clinker, and presents superior mechanical properties and durability [5].

Clays from different sources have different properties. In hydration reactions, kaolinitic clays are very effective [10]. Metakaolin (MK) obtained through the calcination of kaolinite 
clays is the most traditional SCM due to its high reactivity. MK blended cements have been found to show a high sulfate resistance, low chloride attack, higher strength, and significant pore structure refinement [10]. Although MK is much more reactive, its degree of reactivity is restricted by the presence of $\mathrm{Ca}(\mathrm{OH})_{2}$ obtained during the hydration of OPC.

In blended cements, the early use of hydration is predominantly affected by the chemistry of the pore solution ( $\mathrm{pH}$, dissolved ions, and water activity) and the physical effects of the SCM used. On the other hand, in later stages, the hydration is affected because of the filler effect, and accelerates over time. This is divided into three parts: (i) "dilution effect", (ii) "nucleation effect", and "accelerated dissolution effect". However, it has been reported that the special surface properties of CC also affect the above-mentioned processes to different extents. The early strength development in CC blended cement is affected considerably by the sulfate content and adjustment of the sulfate carrier is mandatory [11,12]. This aspect requires in-depth investigation.

Nano-materials in general improve the properties of cement, but due to their high cost, their uses are limited $[13,14]$. On the other hand, nano-clay is economical and can be obtained in large amounts and is more effective. However, the calcining temperature is an important factor influencing the activity of calcined nano-clay.

In addition to cement and concrete, geopolymer concrete is also going to be an important construction material in the future because of its high mechanical properties and durability in aggressive atmospheres [15]. A wide variety of materials can be used to make geopolymers, among which slag, fly ash, and MK have been extensively used. Clay minerals are easily available and cost effective, and are being used for geopolymer production. However, different types of clays have different influences on the properties. The overall mechanism of geopolymers made from clay is not well understood [16].

Air dried bricks, first made in around $4500 \mathrm{BCE}$, were made of clays [17]. Firing is important for making bricks because porosity is reduced during firing, with an increase in mechanical strength. There are variety of clay minerals used when making bricks. Normally, brick manufacturers define clays based on their particle sizes [18]. However, different clay minerals modify brick properties depending on their crystal structures, compositions, elements, plasticity, and shrinkage behaviors [19,20]. All these aspects need to be understood.

Our literature survey clearly indicates that clays and clay minerals play an important role in the construction industry, particularly as SCMs in cement and concrete, for making geopolymer cement and bricks. How clay and clay minerals modify the properties of the above construction materials have been studied in detail [21-25]. It has been reported that different clay and clay minerals affect the properties in different ways and to different extents. However, there is no single write up with the latest information that discusses the applications of clay and clay minerals for improving the properties of different materials in the construction industry. Therefore, in this review article, the use of clays and clay minerals as materials in the construction industry have been discussed in detail.

\section{Clay Minerals, Classifications and Structures}

Agricola formally defined clay in 1546 [26], although the definition was revised many times, considering the particle size, plasticity, and fire hardening [27]. Clay is an earth material with a plastic character when moist but is hard when fired. It consists of mainly fine particles of hydrous aluminum silicates and other minerals [28]. A group of hydrous aluminum phyllosilicate ("phyllosilicates being a subgroup of silicate minerals") minerals are described by clay. A soft and fine-grained natural rock/earthy material with diameter $<0.005 \mathrm{~mm}$ is called clay. Besides peat, muck, some soils, etc., clays are mainly inorganic materials. Due to erosion and weathering over vast spans of time, rocks containing ceramic clays, soil, clay shales, glacial clays, and the mineral group feldspar (known as the "mother of clay") are formed. During the process of weathering, feldspar is distorted by hydrolysis and results in the formation of clay minerals like smectite and kaolinites. In the presence of small amounts of $\mathrm{Al}_{2} \mathrm{O}_{3}, \mathrm{SiO}_{2}, \mathrm{MgO}$, etc., as well as organic matter, more clay minerals can 
be incorporated into clay [29-31]. Due to the content of water, the geometry, and the particle size, the clays have plasticity and become coherent, stiff, hard, and non-plastic upon firing or drying. The chemical composition of clay affects the plasticity and hardness. When clay retains water, it can be molded into any form. For clay, the particle size is important, but no upper limit has been given to date. On the basis of size and mineralogy, clays can be distinguished from each other [32,33].

Because of the high cation exchange capacity, pore size distribution, and high surface area, it is used as a good adsorbent for water purification. Nano clays are widely used in a number of industries, such as in paper coatings, pesticides, paints, ceramics, pharmaceuticals, construction industry, ion exchangers, separators, plastics, and cosmetics. Clay nanocomposites are also used in different sectors.

Layers of linked silicate tetrahedral and octahedral units constitute clay. About 30 types of nano clays are known and have different mineralogical compositions with different properties [34]. Classifications are mainly made based on the type of combinations of the tetrahedral and octahedral silicate sheets and the way they stack. Some of the clays are "(i) kaolinites, where one octahedral sheet is linked with one tetrahedral (1:1 ratio) (e.g., kaolinite, halloysite, and serpentine); (ii) nonexpanding clays, where one octahedral sheet intercalates between two tetrahedral sheets (2:1 ratio) (e.g., mica and illite); (iii) limited expanding clays (2:1 ratio) (e.g., vermiculite); (iv) strongly expanding clays (2:1 ratio) (e.g., montmorillonite (Mt)); (v) uncharged group (2:1 ratio) (e.g., pyrophyllite and talc); (vi) 2:1:1 group with a brucite octahedral layer between a 2:1 mineral (e.g., chlorites); and (vii) fibrous silicates (e.g., palygorskite and sepiolite)". Weak van der Waals forces are involved in holding the sheets, forming an "interlayer". Negative and positive surface charges are generated due to "isomorphous substitutions in the tetrahedral and octahedral sheets" and $\mathrm{pH}$. The clay minerals classified above are nanoscale materials and are represented in Figure 1 [34].

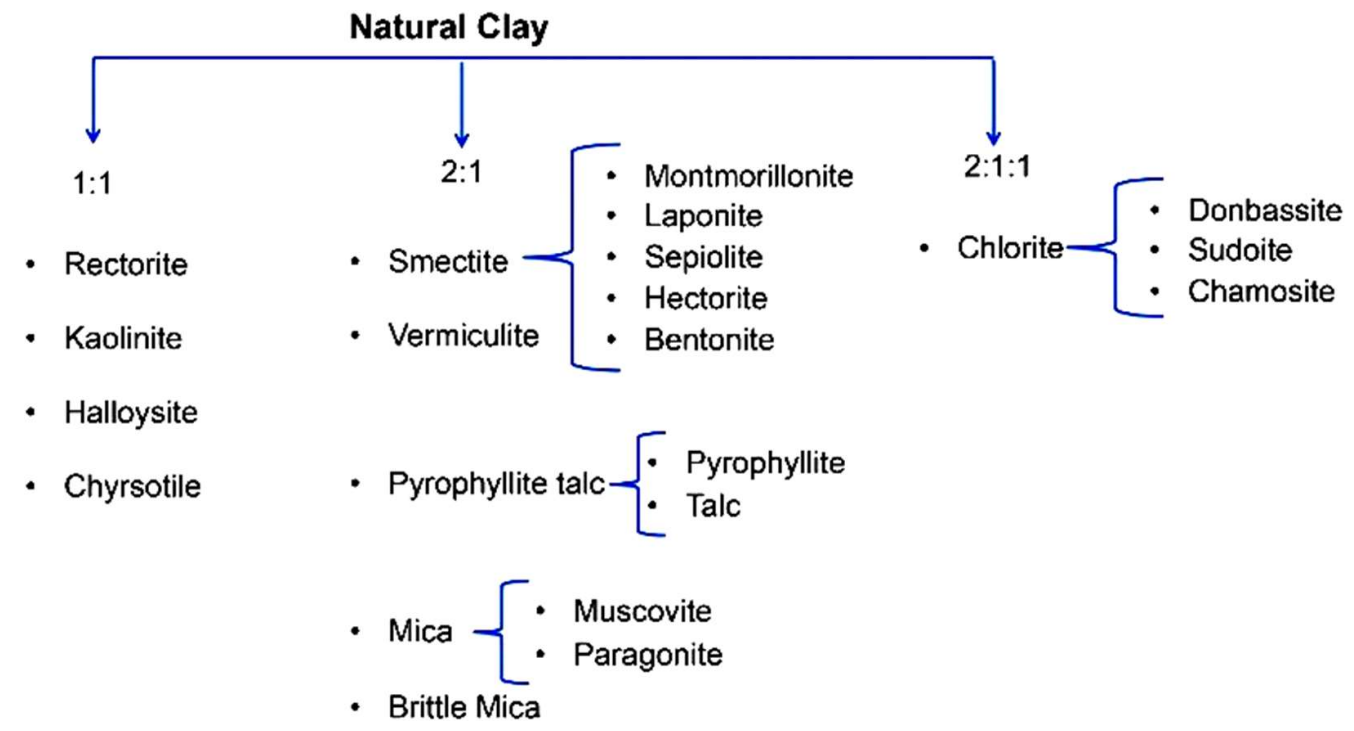

Figure 1. Different types of clay and their classifications.

There are number of clay minerals with different structural features [34-38]. The structural features of some of the clay minerals are discussed briefly. Kaolinite clays have been used for a long period in the ceramic industry, particularly in fine porcelains. The formula of kaolinite is " $\mathrm{Al}_{4}\left[\mathrm{Si}_{4} \mathrm{O}_{10}\right][\mathrm{OH}]_{8}$ " and is a 1:1 type silicate mineral with a tetrahedral silicate layer and a thin sheet of octahedral aluminate. Montmorillonite belongs to a family of expansible 2:1 phyllosilicate clay. The formula of montmorillonite is " $\left(\mathrm{Al}_{1.67} \mathrm{Mg} 0.33\right)$ $\left[\mathrm{Si}_{4} \mathrm{O}_{10}\right][\mathrm{OH}]_{2}-\mathrm{nH}_{2} \mathrm{O}^{\prime \prime}$ with a 2:1 layered lattice. The chemical formula of metakaolin (MK) is $\mathrm{Al}_{2} \mathrm{Si}_{2} \mathrm{O}_{7}$. Smectite consists of beidellite, saponite, montmorillonite (MMT), nontronite, hectorite, and sauconite. Clay minerals with a 2:1 layer are formed by the weathering of 
rocks and soils, belonging to a group of hydroxyl alumino-silicate. MMT may be either calcium- or sodium-based. It is the major clay mineral in smectites. The formula of smectite is " $(\mathrm{Na},-\mathrm{Ca})_{0.3}(\mathrm{Al}, \mathrm{Mg})_{2} \mathrm{Si}_{4} \mathrm{O}_{10}(\mathrm{OH})_{2} \cdot \mathrm{nH}_{2} \mathrm{O}$ ". Illite is like muscovite and is one of the most common clay minerals. Illite has the formula " $(\mathrm{Al}, \mathrm{Fe}, \mathrm{Mg})_{2}\left[(\mathrm{Si}, \mathrm{Al})_{4} \mathrm{O}_{10}\right][\mathrm{OH}]_{2}-\mathrm{nH}_{2} \mathrm{O}^{\prime}$ and is a 2:1 layered structure. Bentonite is mainly formed by smectite clay minerals, hydrothermal synthesis, and chemical alteration of volcanic ash. The formula for bentonite is $(\mathrm{Na})_{0.7}$ $\left(\mathrm{Al}_{3.3} \mathrm{Mg}_{0.7}\right) \mathrm{Si}_{8} \mathrm{O}_{20}(\mathrm{OH})_{4} \cdot \mathrm{nH}_{2} \mathrm{O}$. Vermiculite is a 2:1 phyllosilicate clay mineral with a highcharge. It Is normally regarded as a weathering product of micas. Phyllosilicates of a small size with a high surface area containing iron and manganese hydroxides constitute clay minerals. Smectite (Sm) and Illite alone constitute about 30\% of all sedimentary rocks [38]. Clay minerals consist of a sheet of edge-sharing $\mathrm{M}_{\mathrm{Oct}} \mathrm{O}_{6}$ octahedra $\left(\mathrm{M}_{\mathrm{Oct}}=\mathrm{Mg}, \mathrm{Fe}\right.$, or $\mathrm{Al}$ ), the octahedral sheet, fused to one or two sheets of corner-sharing $\mathrm{M}_{\mathrm{Tet}} \mathrm{O}_{4}$ tetrahedra $\left(\mathrm{M}_{\mathrm{Tet}}=\mathrm{Si}\right.$ or $\left.\mathrm{Al}\right)$. One or two tetrahedral sheets and one octahedral sheet form a layer of clay mineral. One tetrahedral sheet layer forms a 1:1 type; two tetrahedral sheet layers (on either side of the octahedral sheet) form a 2 type.

\section{Applications of Clays and Clay Minerals}

Clays and clay minerals are very important industrial minerals because of their characteristic physicochemical properties and their variety of applications in different industrial sectors (Figure 2). They are used in a number of industries such as ceramics, cosmetics, biomedical, health care, energy, construction, environmental remediation, food packaging, clothing and paints, soil fertility, radioactive waste disposal, etc. Clay minerals are also used for the preparation of different composites used in different ways. However, in this review article, the applications of clays and clay minerals in the construction industry with reference to cement and concrete, geopolymer cement, and bricks are discussed.

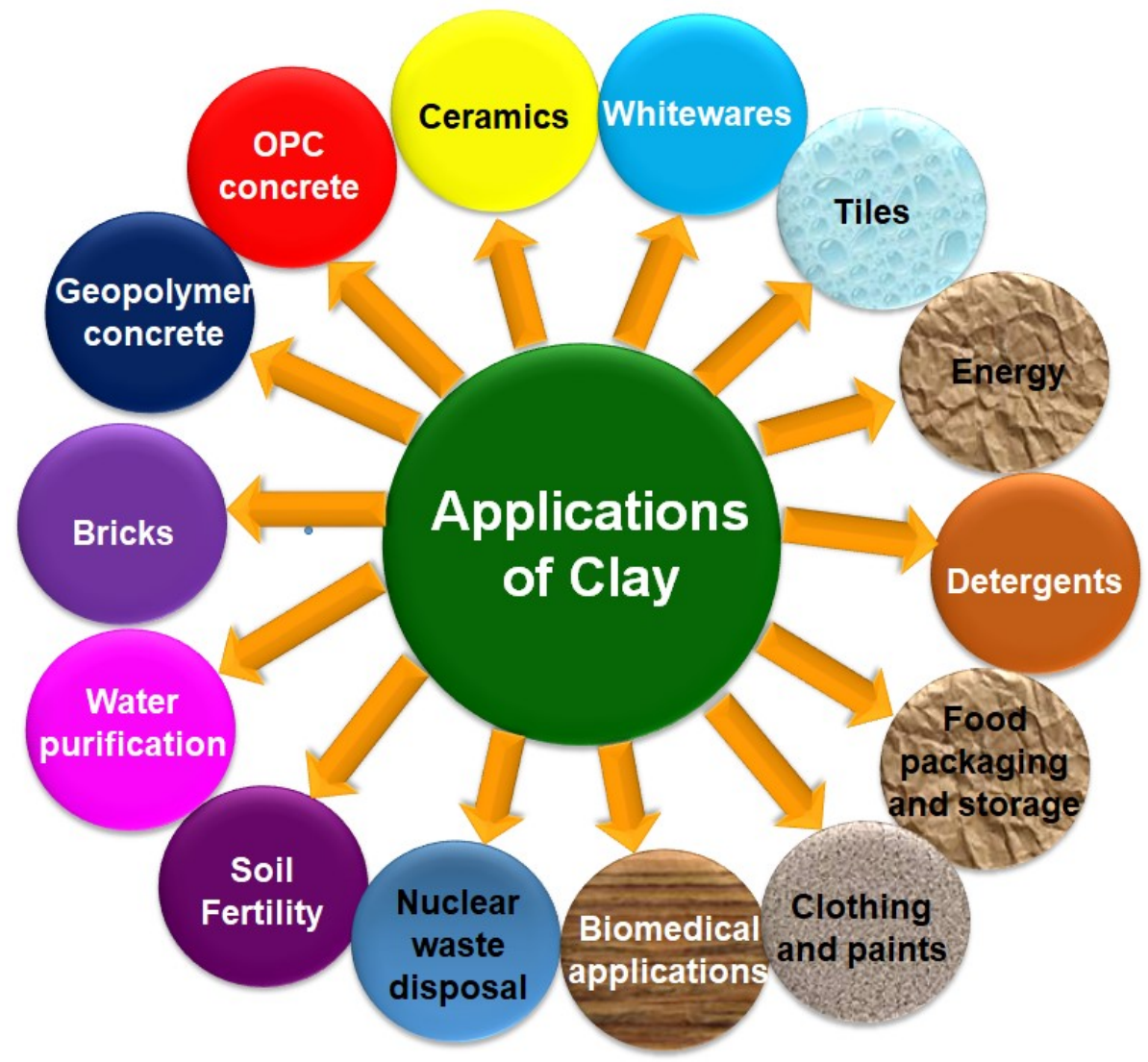

Figure 2. Applications of clay in different sectors. 


\section{Clay and Clay Minerals in the Construction Industry}

i. In the construction industry, the following are the most important components

ii. Cement and concrete

iii. Limestone calcined clay cement $\left(\mathrm{LC}^{3}\right)$

iv. Geopolymer and concrete

v. Bricks

For all of the above, clay and clay minerals are used in one way or another. In the following section, their applications are discussed.

\section{Cement and Its Hydration in Presence of Calcined Clay}

During the early period of civilization, clay was frequently used as the most important construction material. Examples of this are roof tiles, blocks, and bricks [39]. Nowadays, cement is the most important construction material used all over the world. Global cement production is continuously increasing, with China in the number one position. However, after China, India is at number 2. A huge amount of $\mathrm{CO}_{2}$, responsible for global warming, is emitted during cement production [40]. When part of the clinker in cement is replaced by supplementary cementitious materials (SCMs), the quality of cement is improved, and $\mathrm{CO}_{2}$ emission is reduced [41]. There are a number of SCMs, e.g., fly ash, rice husk ash, granulated blast furnace slag, and silica fume, but their availability is limited. Now, CCs containing kaolinite are used as sustainable SCMs [42]. The early strength of calcined clay blended cement develops at a lower rate than pure cement. Based on the type of calcined clay, the development of the later strength is increased [43].

Many clay-based SCMs have been produced. Some examples are flash calcined clay, calcined clay, mechanically activated kaolin, and MK. Out of all of these, MK has drawn significant attention due to its many advantages [44]. In the presence of water, $\mathrm{Al}_{2} \mathrm{O}_{3}$ and $\mathrm{SiO}_{2}$ of $\mathrm{MK}$ react with $\mathrm{CH}$, leading to the formation of calcium aluminate hydrates $(\mathrm{CAH})$, calcium-silicate hydrate (CSH), and calcium alumino-silicate hydrates (CASH) [44]. The gel formed blocks the capillary pores of concrete. In many cases, MK exhibits a pozzolanic activity like silica fume (SF) [44]. This is because of the high Al-content. MK changes the initial and final setting times of mortar and concrete, which depends on the reactivity of the $\mathrm{MK}$ and $\mathrm{Al}_{2} \mathrm{O}_{3}$ content, type of cement, finesse of $\mathrm{MK}$ and $\mathrm{OPC}$, and the dosage of superplasticizer (SP). MK sometimes has a greater accelerating effect than SF in early ages [45] and sometimes has a retarding effect due to the slower hydration-kinetics than OPC [46]. In general, MK increases the packing density and the pozzolanic reactions are increased. The service life of RC structures in marine and harsh environments is increased in the presence of MK due to the increase in corrosion resistance [44].

The major hydration reactions in calcined clay (CC) blended cement produce C-S-H and $\mathrm{CH}$ due to $\mathrm{C}_{3} \mathrm{~S}$ and $\mathrm{C}_{2} \mathrm{~S}$ hydration [47].

$$
\begin{gathered}
\text { “ } 3 \mathrm{CaO} \cdot \mathrm{SiO}_{2}+n \mathrm{H}_{2} \mathrm{O} \rightarrow x \mathrm{CaO} \cdot \mathrm{SiO}_{2} \cdot(n-3+x) \mathrm{H}_{2} \mathrm{O}+(3-x) \mathrm{Ca}(\mathrm{OH})_{2}, \\
2 \mathrm{CaO} \cdot \mathrm{SiO}_{2}+n \mathrm{H}_{2} \mathrm{O} \rightarrow x \mathrm{CaO} \cdot \mathrm{SiO}_{2} \cdot(n-2+x) \mathrm{H}_{2} \mathrm{O}+(2-x) \mathrm{Ca}(\mathrm{OH})_{2} \text { ". }
\end{gathered}
$$

When CC is used as a partial substitute for clinker, the pozzolanic parts of CC react with $\mathrm{CH}$ to form additional C-S-H and mitigate the expansive effect of ASR and ACR. Additional SCCs, such as CSH, CAH, and CASH, are also formed.

$$
\mathrm{Al}_{2} \mathrm{O}_{3} \cdot 2 \mathrm{SiO}_{2} \text { (calcined clay) }+\mathrm{Ca}(\mathrm{OH})_{2}(\mathrm{OPC} \text { hydration })+\mathrm{H}_{2} \mathrm{O} \rightarrow \mathrm{CSH}+\mathrm{CASH}
$$

Furthermore, $20 \mathrm{wt}$ \% CC (20CC) reduces the heat of hydration [48]. During the hydration of cement, the first peak comes as a result of silicate, particularly, $\mathrm{C}_{3} \mathrm{~S}$ hydration; the second peak is due to $\mathrm{C}_{3} \mathrm{~A}$ dissolution; and third peak is due to sulfate depletion and renewed ettringite formation. The same type of peaks appear in the presence of $20 \%$ calcined clays (20CC) and the reaction occurs at a faster rate. The results indicate that in the presence of CC, the hydration sequence does not change. The depletion of sulfate peaks is 
visible in both cases. In the presence of microlimestone ( $\mu \mathrm{LS})$, the acceleration of hydration is more compared to that in the presence of 20CC alone. The role of $\mu \mathrm{LS}$ in enhancing hydration may be due to a seedling effect. The formed C-S-H seeds might cover the cement grains after $24 \mathrm{~h}$ (Figure 3) [48]. The SEM pictures after one day indicated that the amount of C-S-H in the gel phase increased in the cement with CCs (Figure 3B). In the presence of $\mu \mathrm{LS}$ and $\mathrm{C}-\mathrm{S}-\mathrm{H}$, the micrographs showed long ettringite needles (Figure 3C,D).
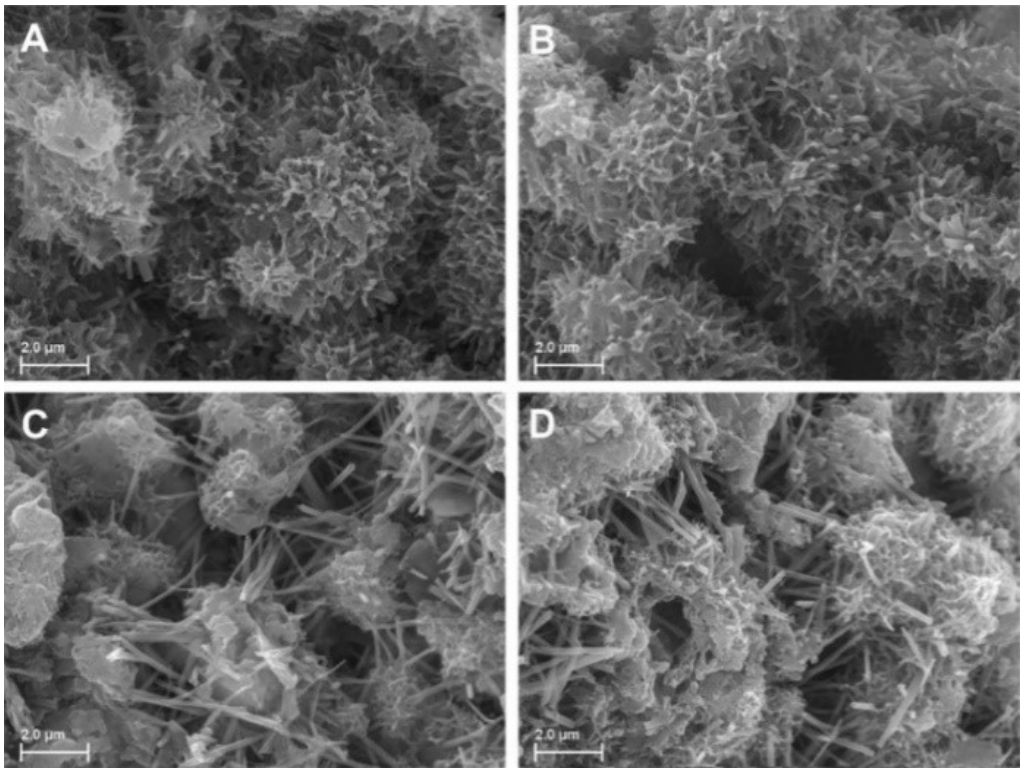

Figure 3. SEM pictures at 24 h: (A) reference, (B) 20CC, (C) 20CC-10 $\mu$ LS, and (D) 20CC-3C-S-H [48].

The effect of thermally made MK and mechanically activated MK (AK) on the hydration of cement has been studied [49]. At 90 days, 20MK in mortar gives a higher compressive strength compared to the reference, whereas in presence of AK, the compressive strengths of mortars are lower [50,51]. The differences in the compressive strengths in the presence of MK and AK may be due to the partial amorphization of AK [51]. The high values of compressive strength in the presence of MK in mortars may be due to the higher content of reactive silica.

Nanomaterials affect the properties of cement and concrete. Nano-metakaolin (NMK) acts better than nano- $\mathrm{SiO}_{2}$ and nano- $\mathrm{CaCO}_{3}$ [52]. $\mathrm{NMK}$ is a derivative of kaolin $\left(\mathrm{Al}_{2} \mathrm{O}_{3} \cdot 2 \mathrm{SiO}_{2} \cdot 2 \mathrm{H}_{2} \mathrm{O}\right)$ and promotes the nucleation, consume free $\mathrm{CH}$, and also forms needlelike secondary hydration products. In the presence of $\mathrm{NMK}$ in cement, $\mathrm{H}_{2} \mathrm{SiO}_{4}{ }^{2-}$ is formed, which reacts with $\mathrm{Ca}^{2+}$, forming additional $\mathrm{C}-\mathrm{S}-\mathrm{H}$. This densifies the structure (Figure 4) [53]. For the acceleration of hydration, an optimum amount of NMK is needed. NMK also fills the pores and forms a compact structure, and is responsible for the high mechanical properties [54-56].

Due to the high surface energy of NMK, there is thermodynamic control over the process [53]. The thermodynamic drive is reduced due to precipitation on the NMK surface. The growth of the hydrate phases starts when ion concentrations exceed saturation. Normally, growth starts when the nuclei reach a certain critical size, but in this case, it is different. NMK, in the meantime, generates a new nucleus for the hydration process, helping with the continuous growth of the $\mathrm{C}-\mathrm{S}-\mathrm{H}$ phase on the NMK surface. The nucleus of crystal is beneficial for increasing the early strength of cement [57]. After the completion of hydration, the nucleation effect becomes negligible [58]. 

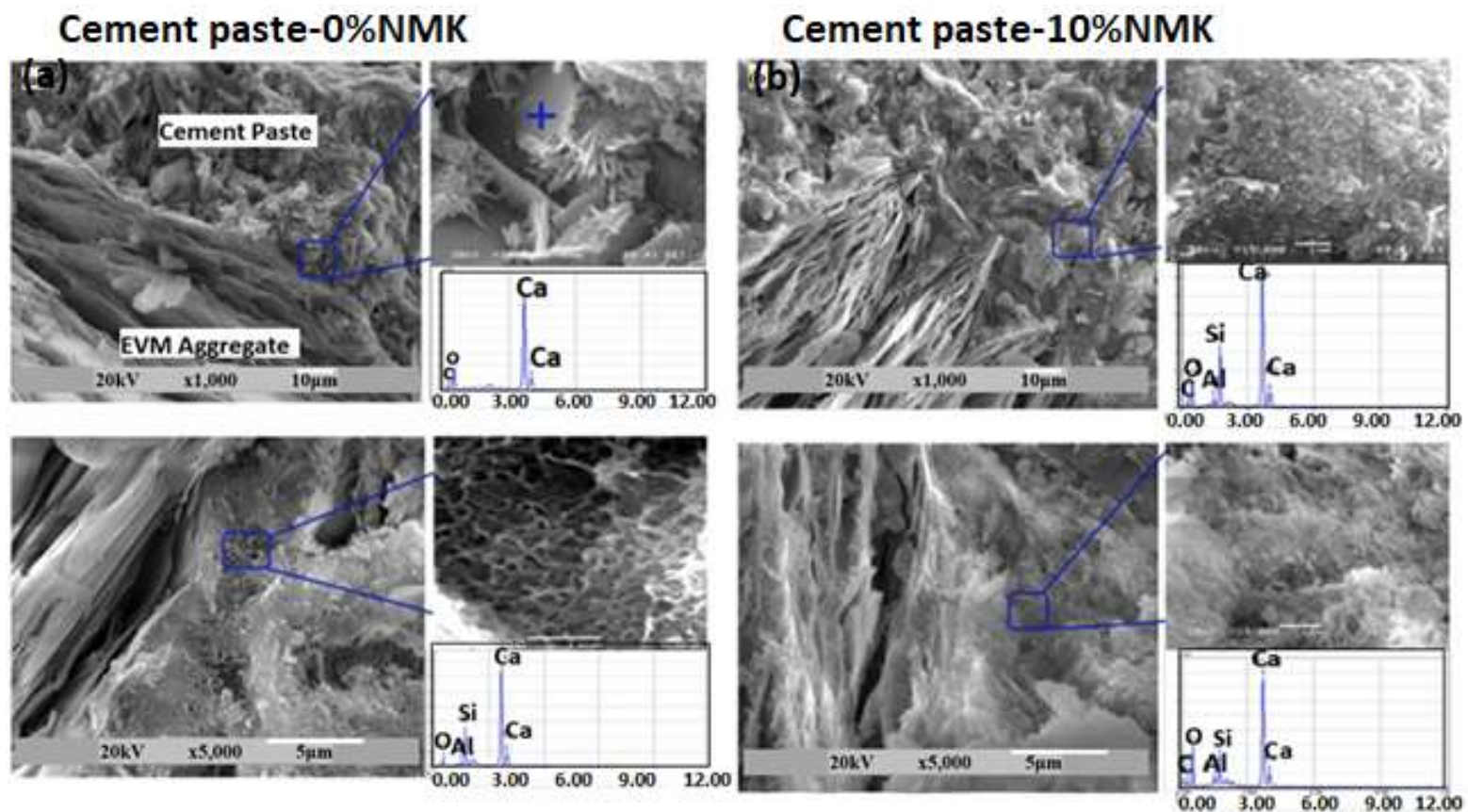

Figure 4. SEM pictures and EDAX of (a) $0 \%$ NMK and (b) 10\% NMK [53].

In the presence of sulphate ions, there is an interaction of sulphate ions with $\mathrm{Ca}(\mathrm{OH})_{2}$ and calcium aluminate hydrate, with the formation of gypsum and ettringite, resulting into the deterioration of the concrete structure. When MK is added to concrete, the sulfate resistance is increased. A considerable amount of research has been done on the role of calcined kaolinite (metakaolin) regarding the risk of sulphate in concrete [59,60]. Sulfate resistance increased with the increase of metakaolin (Figure 5) [60]. With increasing the sulfate exposure period, the expansion of MK concrete increased steadily and continuously because of the slow and continuous intrusion of sulfate ions into concrete specimens. By consuming $\mathrm{CH}, \mathrm{MK}$ significantly affects concrete durability exposed to a sulfate environment $[60,61]$. MK reduces the corrosion of concrete, even at high chloride contamination $[62,63]$.

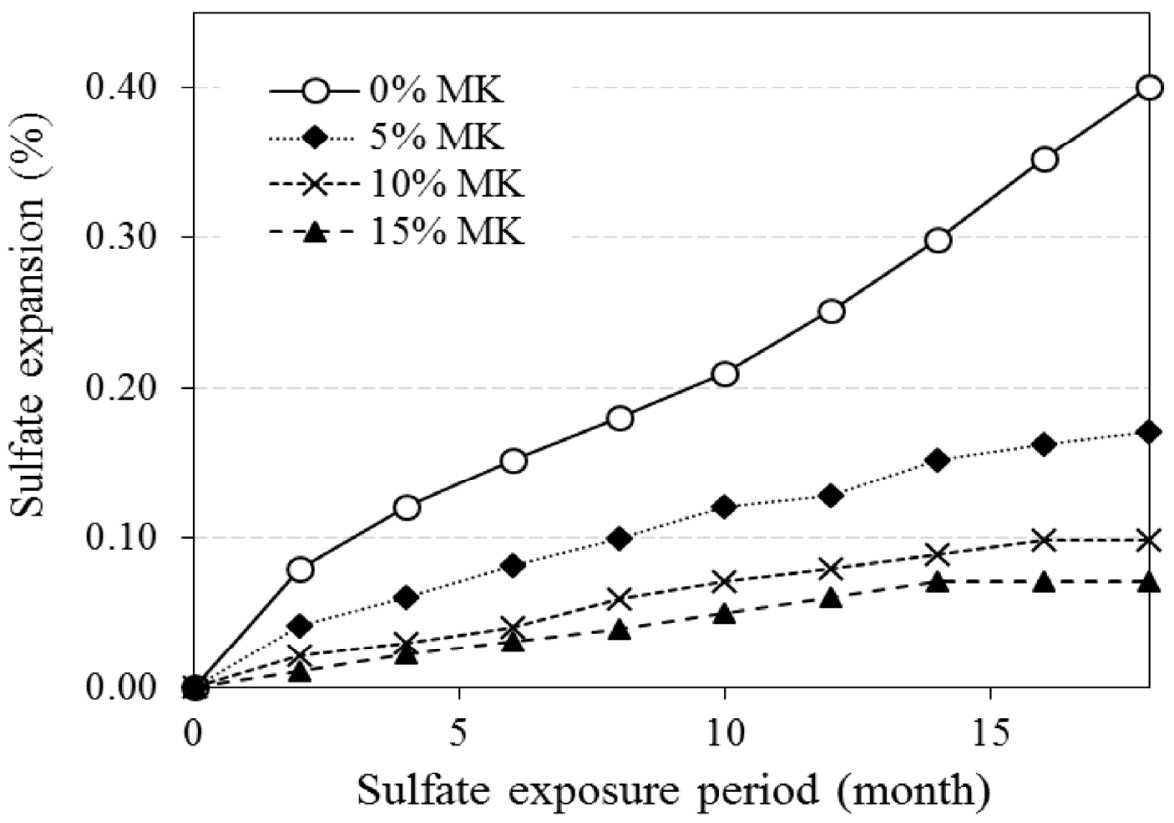

Figure 5. Effect of MK on sulfate expansion with time at a $w / b$ ratio of 0.5 . 


\subsection{Limestone Calcined Clay Cement $\left(L C^{3}\right)$}

Due to the economic and environmental advantages of $\mathrm{LC}^{3}$, considerable research has been done during the last decade [64]. In recent years, $\mathrm{LC}^{3}$ has been gaining the attention of engineers and researchers as an important alternative to Portland cement $[64,65]$. It is made by blending clinker, calcined clay, limestone, and gypsum, as shown in Figure $6[64,65]$. It is a new type of cement, reduces $\mathrm{CO}_{2}$ by up to $40 \%$, uses low grade raw materials, and requires a lower calcination temperature for clay. It is cost effective and does not require major modification in cement plants.

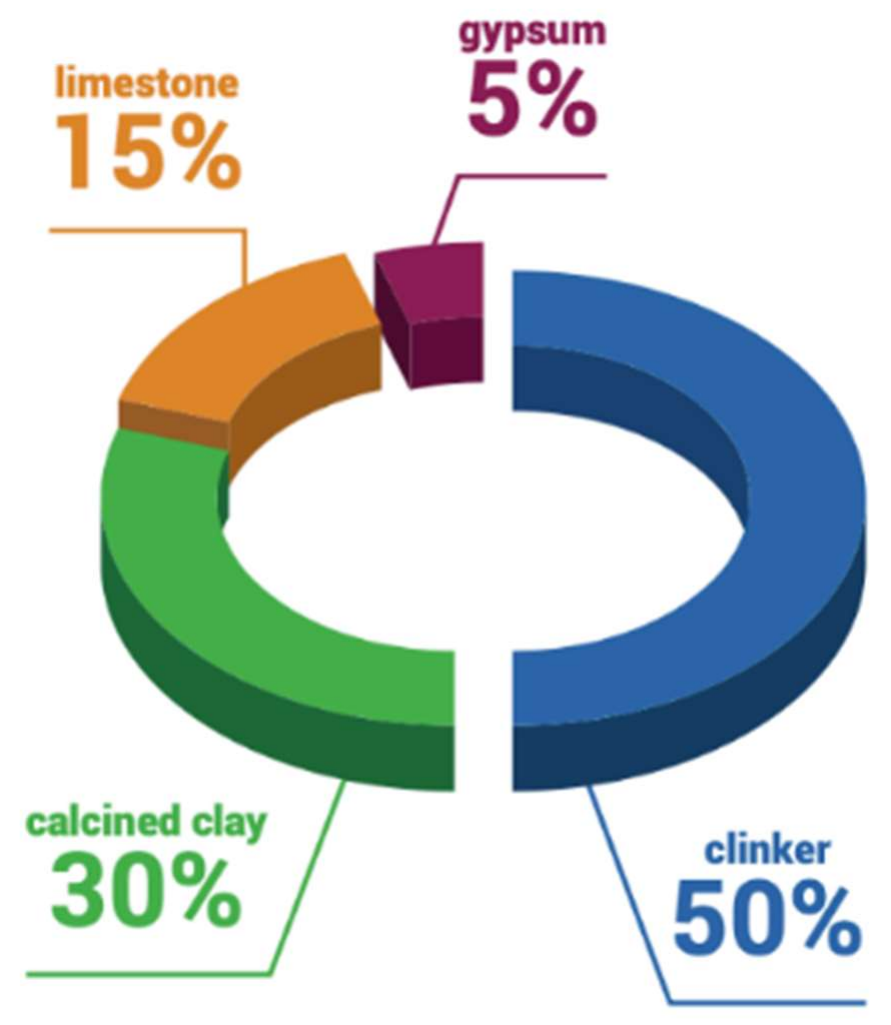

Figure 6. Preparation of $\mathrm{LC}^{3}$ by blending different constituents.

Among the different types of clays, calcined clays show the highest pozzolanic activity [66-70]. In $\mathrm{LC}^{3}-50$, he clinker content can be reduced to $50 \%$ and the strength varies linearly with the kaolinite content [70]. When adding $40 \%$ calcined kaolinite, higher strengths than OPC mortars are obtained after 7 days, irrespective of clay fineness. MK acts as a pozzolanic material forming C-A-S-H, AFm phases, and ettringite [71,72]. After adding limestone in $\mathrm{LC}^{3}$, carboaluminate phases are formed [73].

$\mathrm{LC}^{3}$ can be compared with conventional cement and it has a number of properties (Figure 7).

The heat evolution profiles of $\mathrm{LC}^{3}$ per gram of solid (a) and per gram of clinker (b) for OPC and $\mathrm{LC}^{3}-50$ for $0 \%, 50.3 \%$, and $95.0 \%$ are shown in Figure 8 [70]. The induction period was slightly decreased for $\mathrm{LC}^{3}-50$ blends because of the addition of a superplasticizer. The delay increased with the addition of the calcined kaolinite content. In the $\mathrm{LC}^{3}-50$ blends, the hydration of $\mathrm{C}_{3} \mathrm{~S}$ was enhanced due to the filler effect of the calcined clay. The calcined clay significantly affected the intensity of the aluminate peak. The intensity of the peak increased with the calcined kaolinite content. Furthermore, the increase in heat could be explained by the start of the metakaolin reaction with portlandite. 


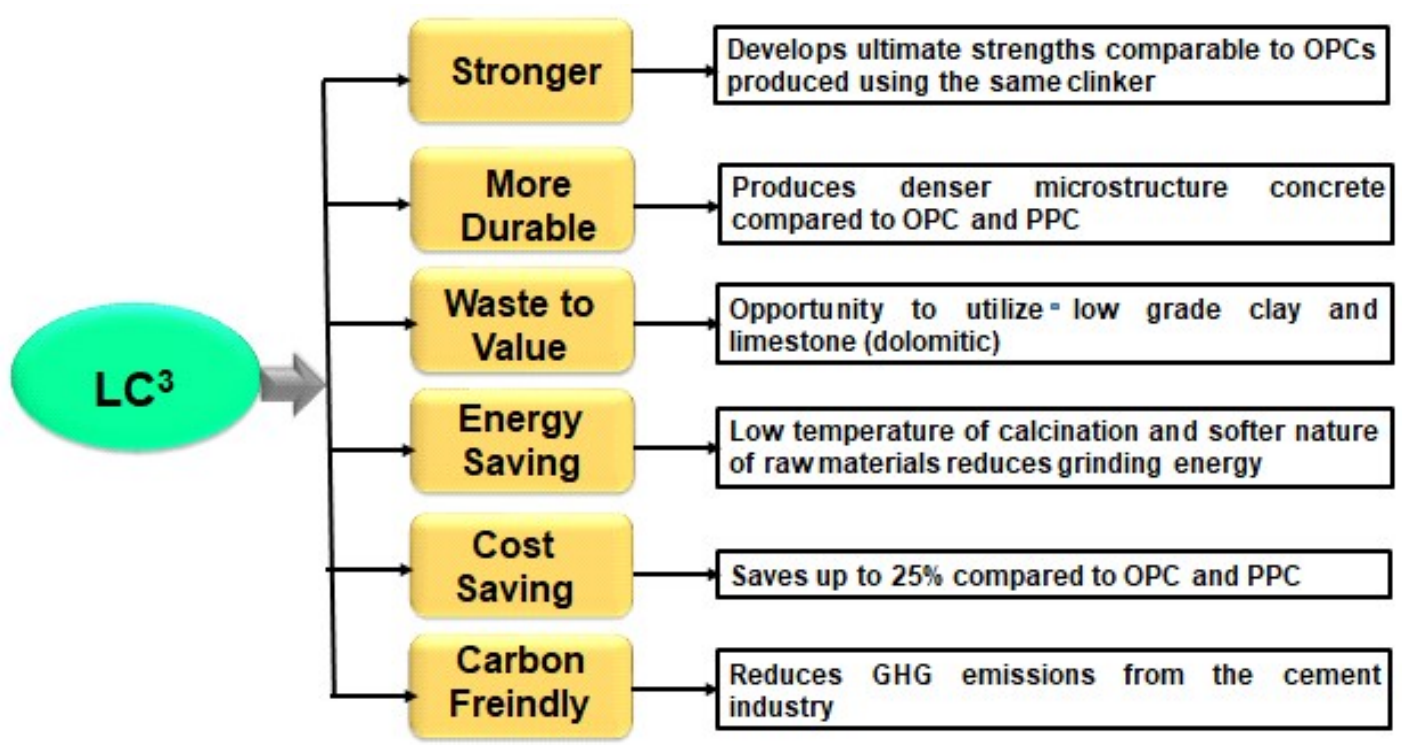

Figure 7. Properties of $\mathrm{LC}^{3}$.

a)

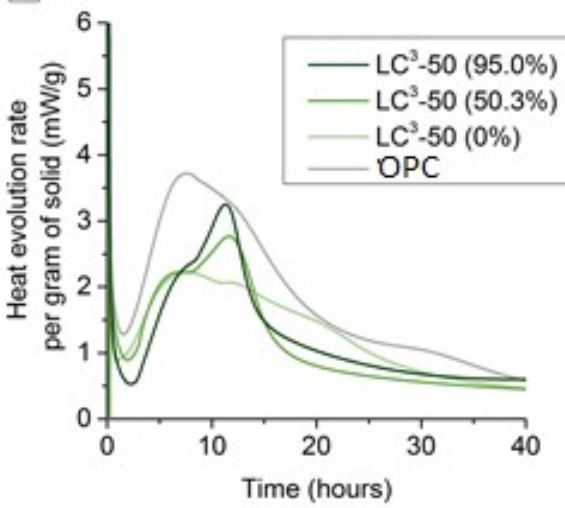

b)

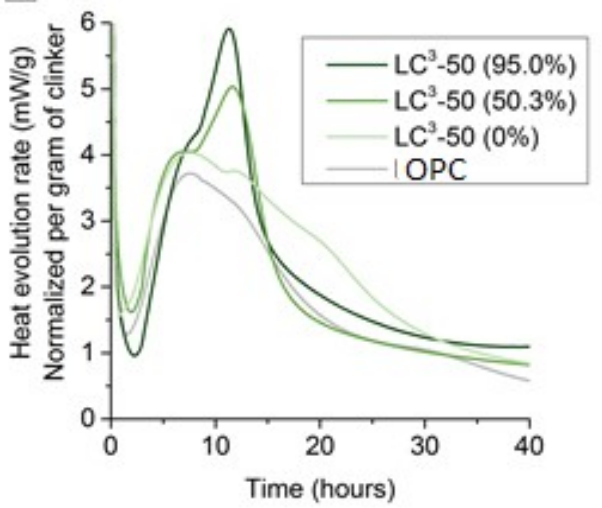

Figure 8. Heat evolved: (a) normalized clinker (b) for PC, LC $\mathrm{LC}^{3}-50$ at $0 \%, 50.3 \%$, and 95.0\% [70].

Thermodynamic modelling of $\mathrm{LC}^{3}$ for $54 \%$ OPC, $30 \%$ calcined clay, $15 \%$ limestone, and $1 \%$ gypsum, at $w / b 0.4$ during hydration has been proposed (Figure 9) [74]. The formation of different reaction products and the consumption of reacting components are also shown in Figure 9. The carboaluminate (Mc) content increased until about $12 \% \mathrm{MK}$ reacted, and then decreased as the stratlingite started to precipitate. In thermodynamic modelling, normally only $\mathrm{Mc}$ is observed, as pure hemi carboaluminate (Hc) as a metastable phase. A significant variation in the $\mathrm{C}-\mathrm{A}-\mathrm{S}-\mathrm{H} \mathrm{Ca} / \mathrm{Si}$ ratio over the reaction range of $\mathrm{MK}$ is shown by thermodynamic modelling, especially after the complete consumption of portlandite. From the thermodynamic modelling, it has been predicted that stratlingite is not expected to be formed, even if all MK available reacts in the systems.

Compressive strength development of $\mathrm{LC}^{3}$ concretes for three grades of concretes for $25 \mathrm{MPa}, 32 \mathrm{MPa}$, and $45 \mathrm{MPa}$ of both $\mathrm{LC}^{3}$ and also of conventional concrete (GPC) were measured at different times (Figure 10) [75]. The figure shows that the compressive strength of $\mathrm{LC}^{3}$ concrete was comparable to or even higher in some concretes than that of the conventional concrete after 28 days of water curing. Figure 11 shows the increase of tensile strength of $\mathrm{LC}^{3}$ concrete for up to 28 days of water curing, and the value increased from grade 25 to grade $45 \mathrm{LC}^{3}$ concrete [75]. 

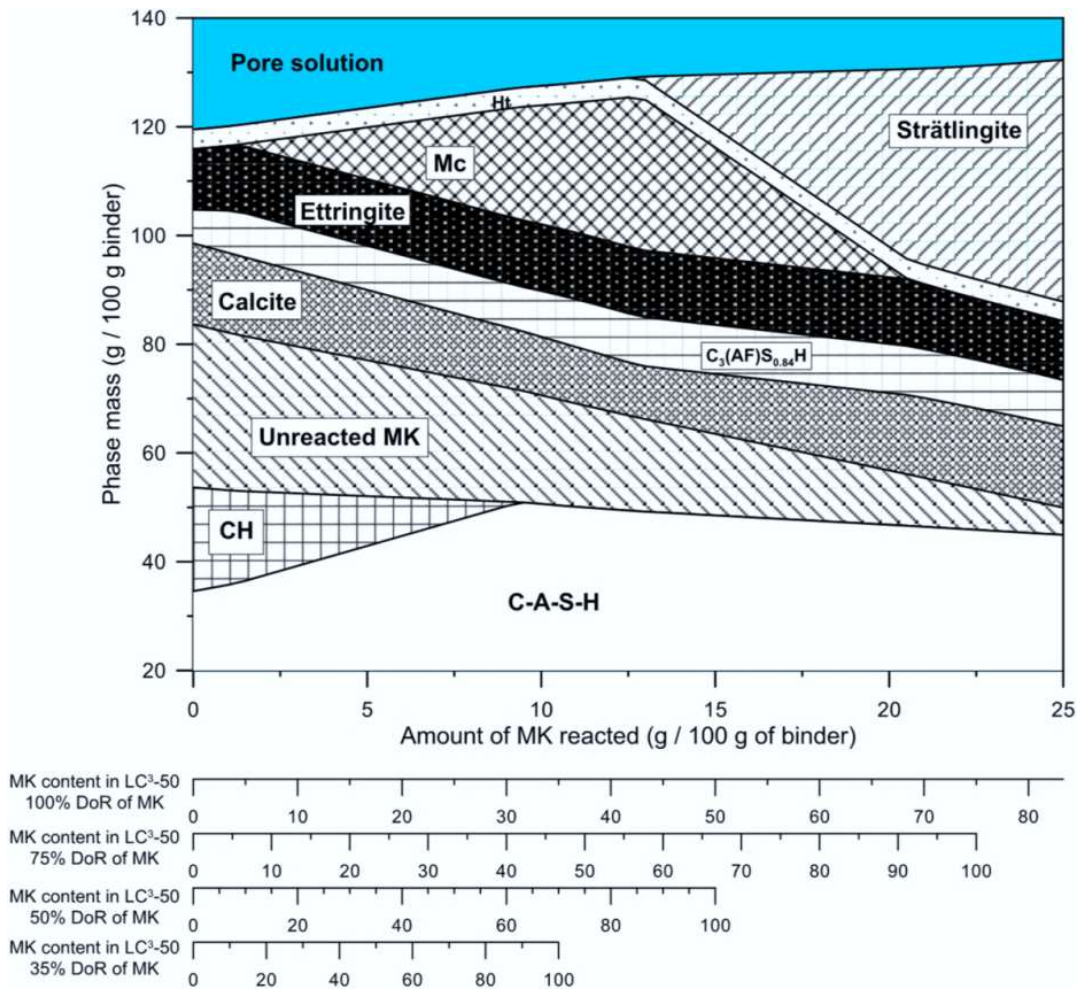

Figure 9. Thermodynamic model for phases of an $\mathrm{LC}^{3}-50$ system in the presence of different amounts of MK [74].

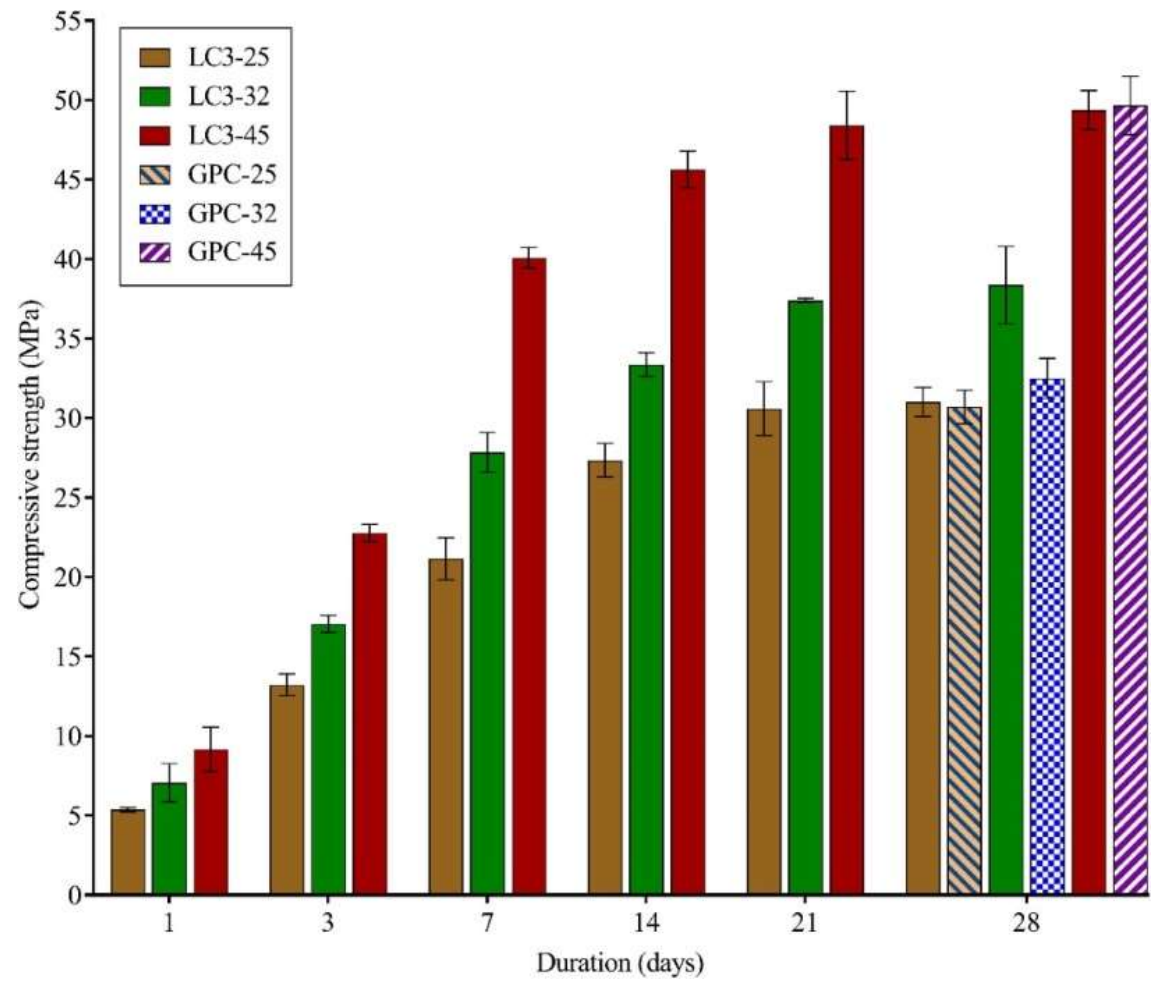

Figure 10. Compressive strength of $\mathrm{LC}^{3}$ and GPC concrete [75]. 


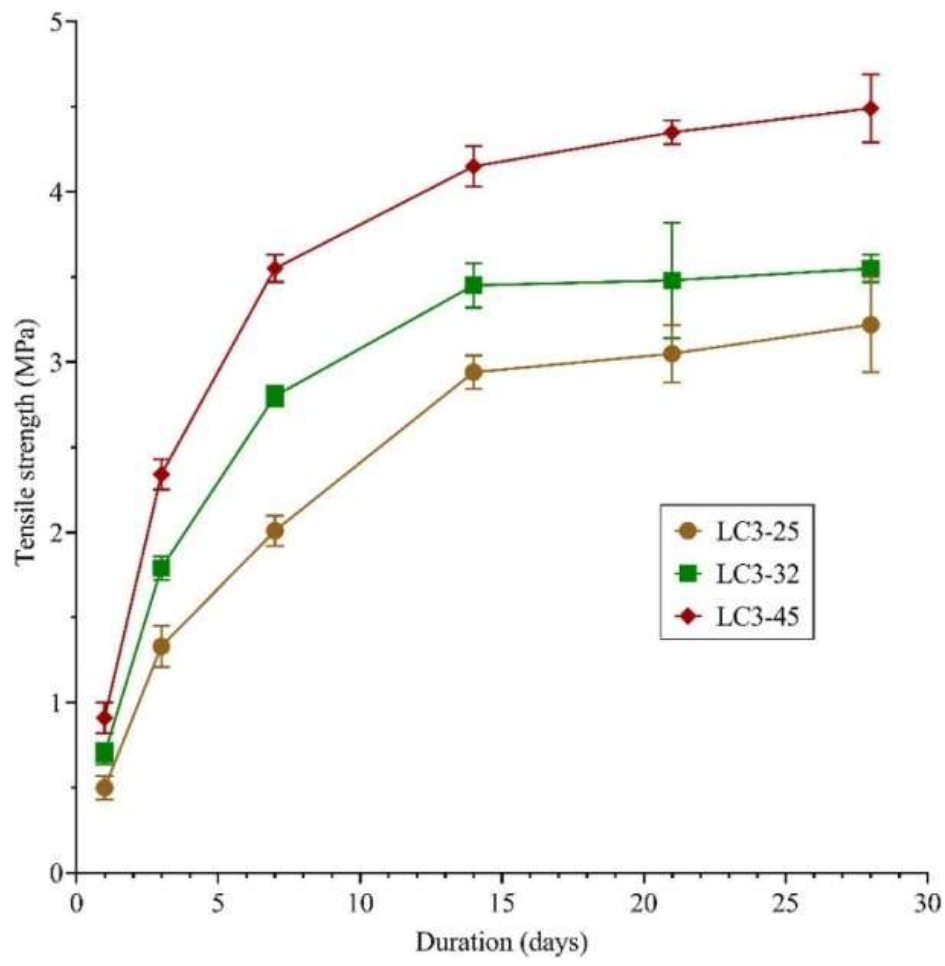

Figure 11. Change of tensile strength with time in $\mathrm{LC}^{3}$ concrete [75].

The OPC in alkali activated cement (AAC) blocks was replaced by $\mathrm{LC}^{3}$ cement. These blocks were used to build non-load bearing walls in a temporary office building in the Embassy of Switzerland, New Delhi, India (Figure 12) [76].

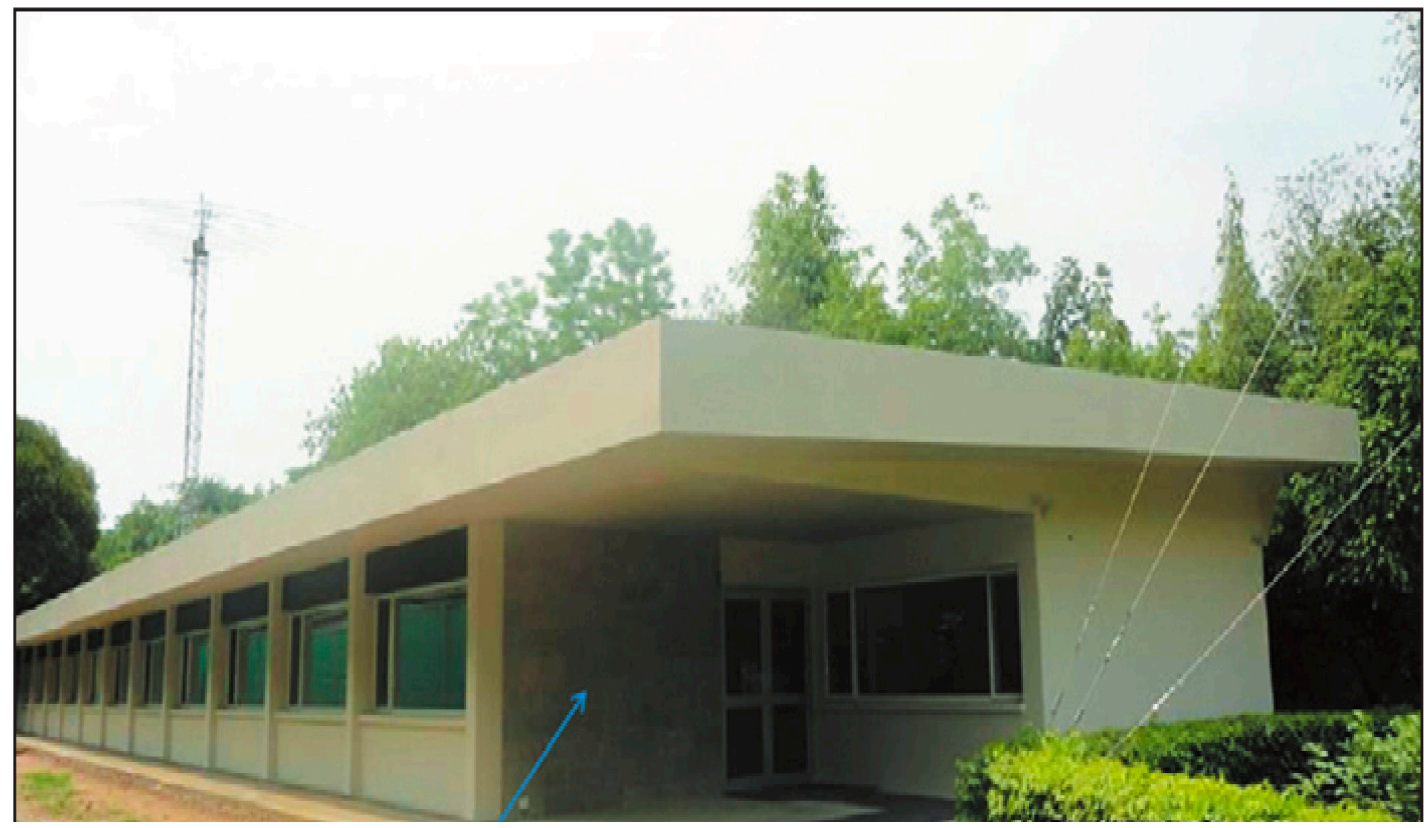

Figure 12. LC $^{3}$ AAC blocks used for an office building in the Swiss Embassy, New Delhi [76].

\subsection{Geopolymer Cement and Concrete}

Development and innovation in science and technology is a continuous process for improving infrastructure all over the globe. For the construction industry, cement and concrete are the most required materials. Every day, new innovative binders are being developed taking into consideration the safety, economics, durability, and environmental 
sustainability in construction industries. After water, concrete is the most used substance in the world. OPC is normally used as the main component for the manufacture of concrete. About 4.6 billion metric tons of OPC are produced every year, which consumes a lot of raw materials and energy. The cement industry alone releases $7 \% \mathrm{CO}_{2}$ into the atmosphere, which is responsible for global warming. In order to overcome these problems associated with OPC production, researchers started searching for new binding materials. In the 1970s, it was pointed out by Davidovits that a fire-proof inorganic polymer obtained by alkali activated alumino silicate materials would be a probable alternative to OPC [77-79]. This polymer was named a geopolymer. In the beginning, this was obtained through the reaction of $\mathrm{MK}$ and $\mathrm{NaOH} / \mathrm{Na}_{2} \mathrm{SiO}_{3}$ or $\mathrm{KOH} / \mathrm{K}_{2} \mathrm{SiO}_{3}$. The $\mathrm{MK}$-based geopolymer gained worldwide interest in the past 40 years, because of its excellent thermal stability and high mechanical property compared to Portland cement [80]. Now, geopolymers are used as a construction material $[81,82]$. The advantages of using geopolymer concrete (including clay-based geopolymers) for various applications in construction are shown in Figure 13.

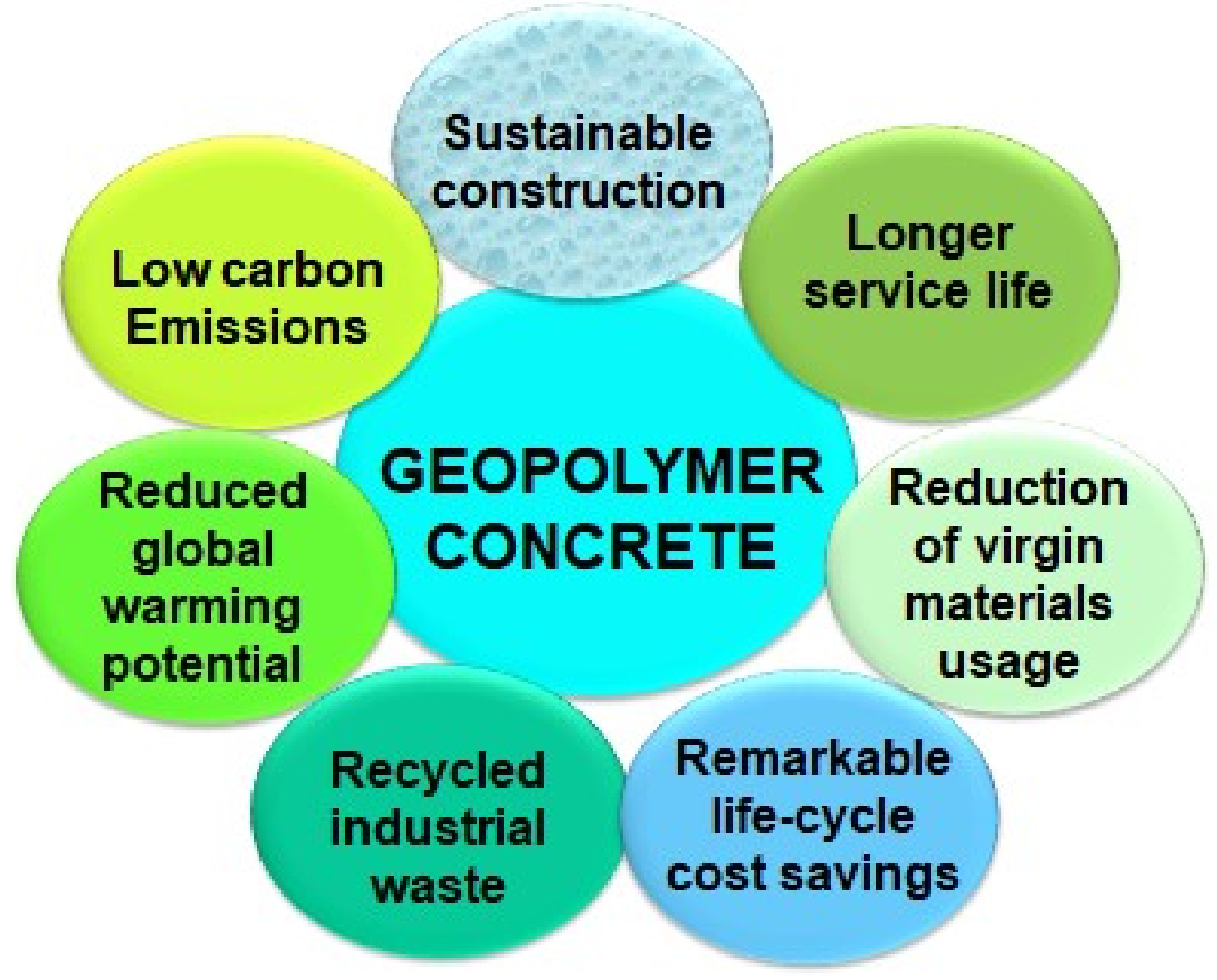

Figure 13. Advantages of geopolymer concrete in construction.

Initially, one of the most abundant source materials containing aluminosilicates used for geopolymer concretes was MK. Natural clays (kaolin) with calcination at a moderate temperature produce MK. In recent years, a considerable amount of research has been done on fly ash-based geopolymers [83-85].

Geopolymers using MK and alkali activators are formed, as shown in Figure 14 [61]. The geopolymer structure is categorized into three forms depending on the $\mathrm{Si} / \mathrm{Al}$ ratios, namely poly(sialate), poly(sialate-siloxo), and poly(sialate-disiloxo) (Figure 15) [86,87]. 


\section{SOLID}

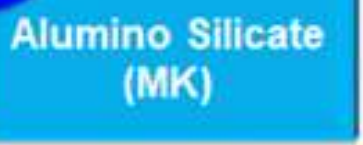

\section{LIQUID}

Alkali Activator

$\mathrm{NaOH} / \mathrm{Na}_{2} \mathrm{SiO}_{3}$ or

$\mathrm{KOH} / \mathrm{K}_{2} \mathrm{SiO}_{3}$

\section{Mixing}

\section{BINDER}

\section{Setting and Hardening}

\section{GEOPOLYMER}

Figure 14. Formation of the geopolymer from MK [86].
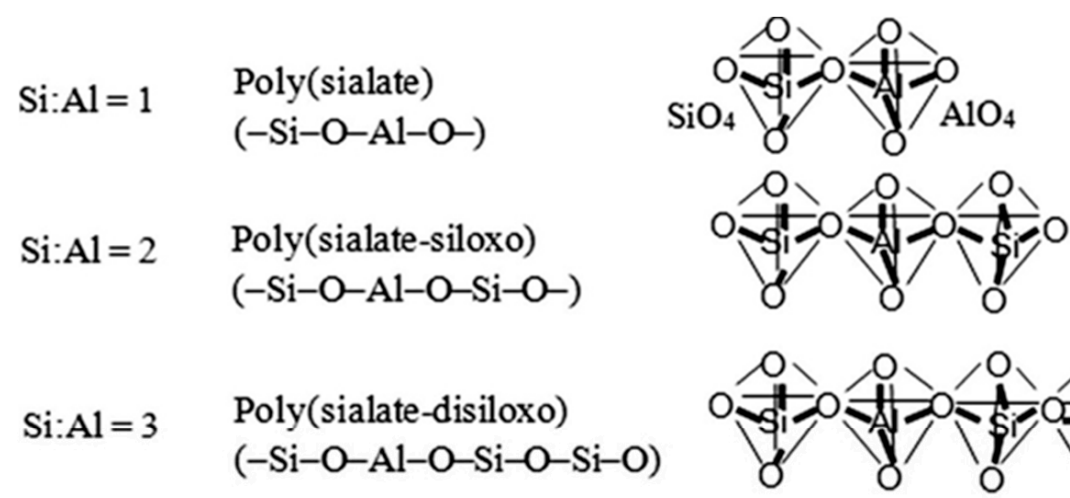

$\mathrm{Si}: \mathrm{Al}>3$ Sialate Link
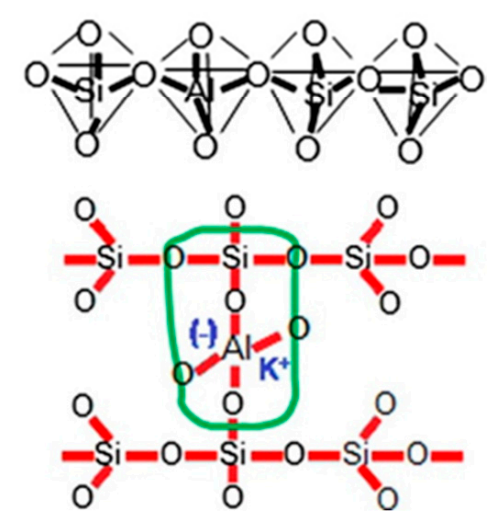

Figure 15. Different geopolymer systems [86].

The empirical formula of geopolymers is

$$
M_{n}\left\{-\left(\mathrm{SiO}_{2}\right)_{\mathrm{Z}}-\mathrm{AlO}_{2}\right\} \cdot w \mathrm{H}_{2} \mathrm{O}
$$

$M$ is a cation, such as $\mathrm{K}^{+}, \mathrm{Na}^{+}$, or $\mathrm{Ca}^{2+} ; n$ is the degree of polycondensation; $z$ is a coefficient; and $w$ is the amount of binding water.

Geopolymerization is an exothermic process, and synthesis occurs through oligomers (dimer and trimer), which produces a three-dimensional structure. Davidovits [88,89] proposed equations for geopolymer formation (Figure 16) [86]. 


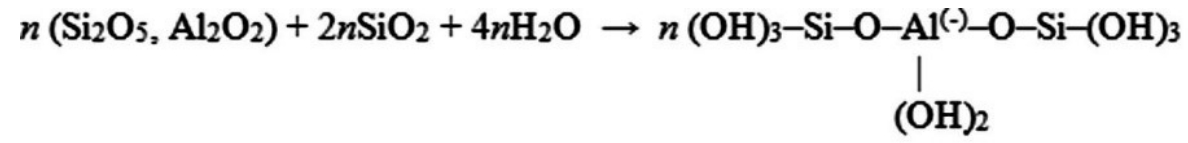

(Geopolymer Precursor)

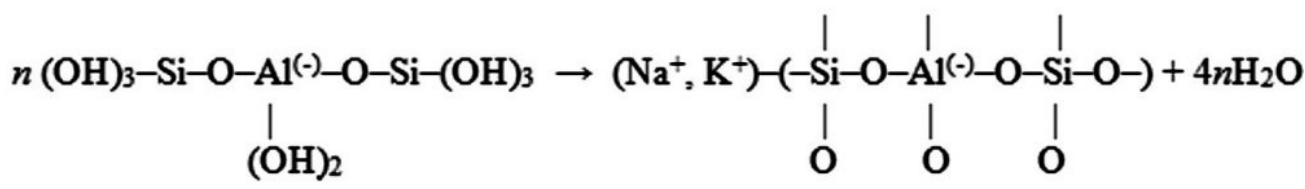

(Geopolymer Backbone)

Figure 16. Geopolymerization reaction.

During geopolymerization, $\mathrm{Si}-\mathrm{O}-\mathrm{Si}$ and $\mathrm{Si}-\mathrm{O}-\mathrm{Al}$ bonds break and are converted to the colloid phase when coming into contact with the alkaline solution. With the advancement of the process, the intermediate phase (Gel 1) was transformed into Gel 2. After this, polymerization occurs and a three-dimensional structure of the geopolymer is formed. The structural model is presented in Figure 17 [86].

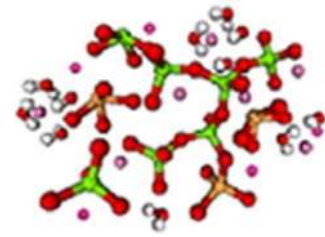

Chemical Attack

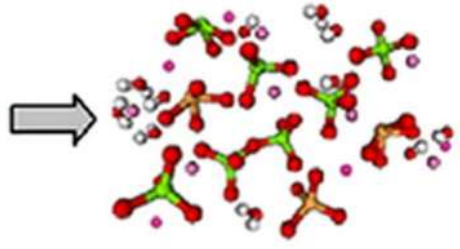

Dissolution

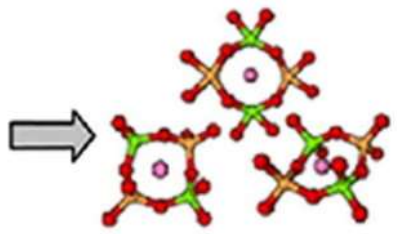

Gel 1

\section{$\mathrm{Si} \mathrm{Al} O \mathrm{Na} \mathrm{OH}$}

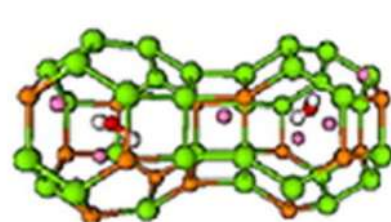

Growth

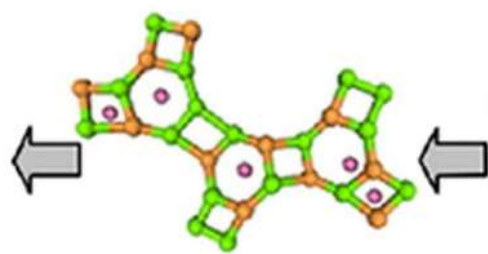

Polymerization

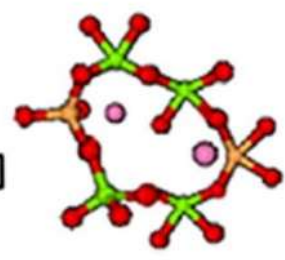

Gel 2

\section{Si $\triangle$ Al $\Delta$}

Figure 17. Structural model of three dimensional geopolymers [86].

When MK is converted to the geopolymer, with the passage of time, hardening occurs and microstructural changes take place [90]. Densification of the structure outside and inside voids occurs.

Different ratios of $\mathrm{Si} / \mathrm{Al}$, water content, concentration, and type $\left(\mathrm{Na}^{+}, \mathrm{K}^{+}, \mathrm{Ca}^{2+}\right)$ of alkali cations affect the mechanical properties, phase transitions, and microstructural features of the geopolymers. Different curing conditions also affect the geopolymerization reactions, affecting the rate of formation and quality of the hard structure. Metakaolin produced by the calcination of kaolin at $800^{\circ} \mathrm{C}$ for $3 \mathrm{~h}$, when cured at different temperatures, the setting times and compressive strengths changed (Figures 18 and 19) [91]. Figure 19 shows that the setting time decreased as the curing temperature increased. However, 
after curing at $40{ }^{\circ} \mathrm{C}$, both the initial and final setting times were merged, indicating solidification of the geopolymer. The compressive strengths increased with temperature and time (Figure 20). The values were the highest at 7 days and $60{ }^{\circ} \mathrm{C}$ curing. After curing at $60^{\circ} \mathrm{C}$, cracking occurred, which lowered the compressive strength.

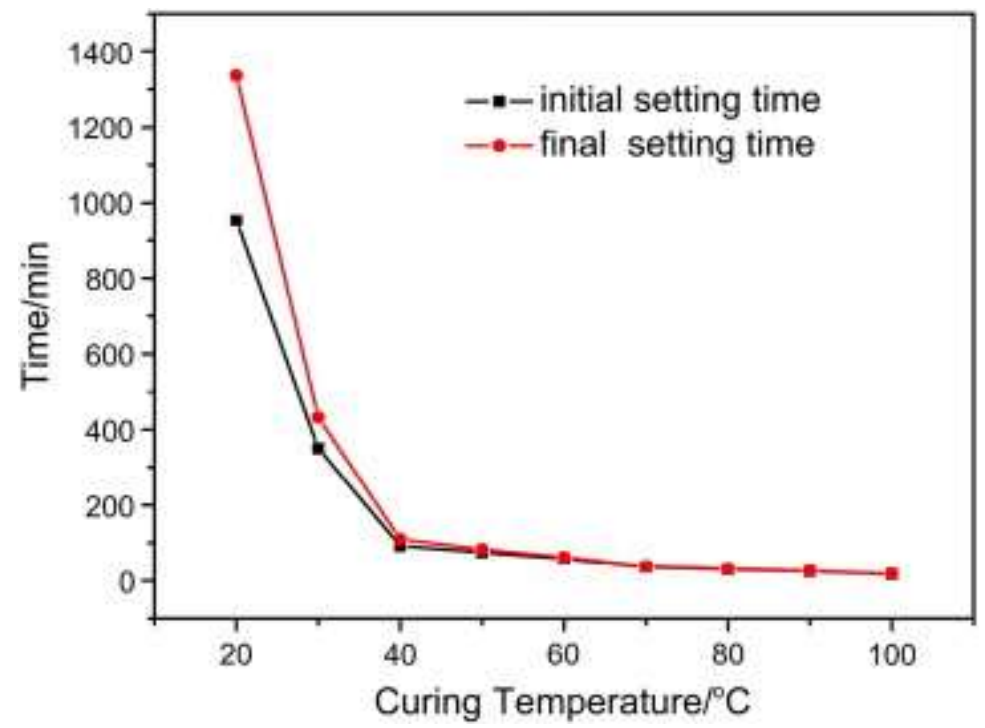

Figure 18. Setting time with temperature [91].

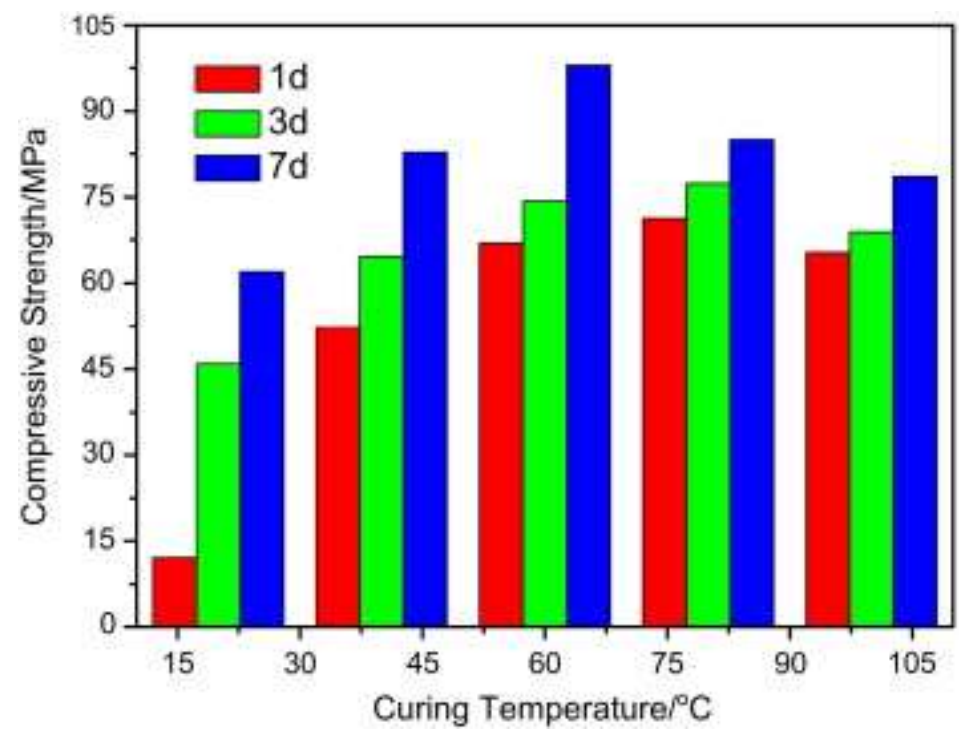

Figure 19. Compressive strength with temperature and time [91].

Furthermore, it has been reported that the replacement of calcined clay with $30 \%$ waste marble is beneficial and improves the compressive strength and paste workability, and mitigates the drying shrinkage. Plastic and early-age shrinkage are also improved [92].

The first building using geopolymer concrete (also clay-based) without OPC was constructed in 1989 (Figure 20) [93]. 


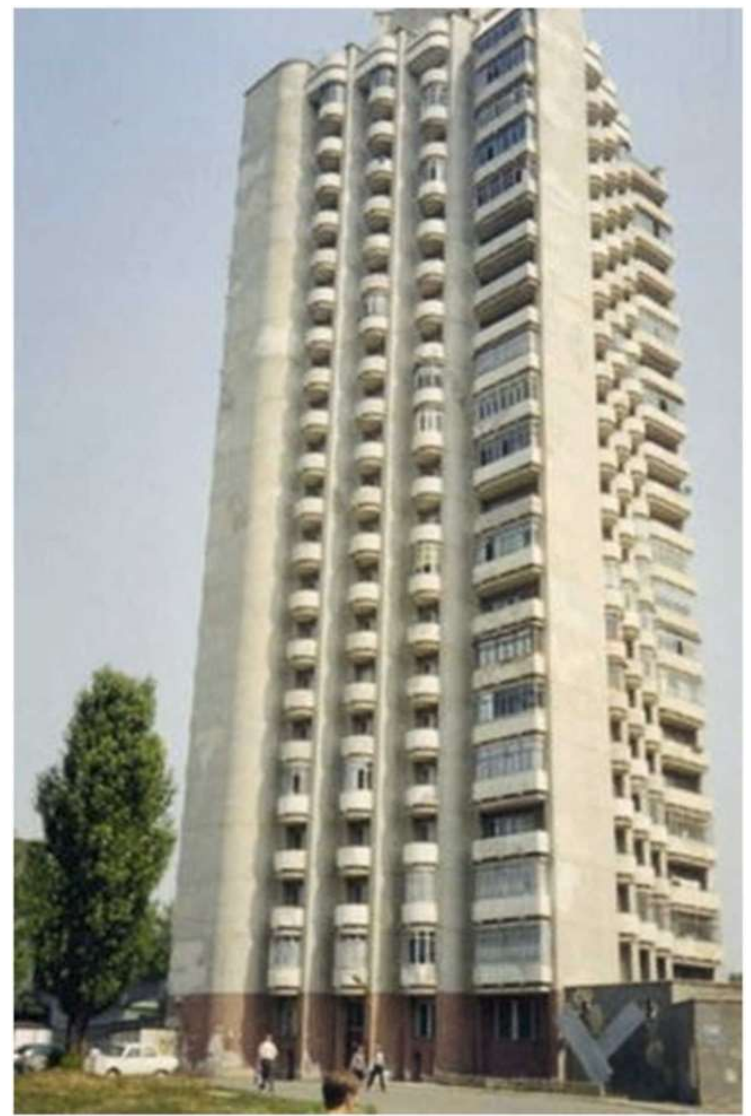

Figure 20. Residential building made using geopolymer concrete without any OPC in 1989 in Lieptsk, the Russian Federation [93].

\section{Clay Bricks}

In small- and large-scale construction, clay-bricks are the most important material and have been in use since the start of civilization. In sub-tropical regions, almost all buildings are built using clay bricks. In different countries, China is the number one for producing clay bricks $[94,95]$. Buildings built with clay bricks in ancient periods have remained intact even in the 21st century. The bricks remained intact even after snow, thaw-freezing cycles, rainstorms, high temperatures (sunlight and fire), and human-induced deterioration [96]. Clay bricks are made through four stages: (1) choice and preparation of clays, (2) mixing and molding, (3) drying in the sunlight, and (4) firing. The quality of bricks depends on the firing temperature and the source of fire. The quality also depends on the materials mixed with clay. A number of waste materials, like glass, are mixed with clay.

Clays are natural materials with different origins and, in brick making, they vary in type and content. Traditionally, brick manufacturers only define clays based on their particle sizes. However, different clay minerals affect brick properties depending on their crystal structures, elemental compositions, plasticity, and shrinkage behaviors [97,98]. At a high molding pressure, the amount of clay plays an important role in developing the strength of bricks. The strength gain mechanism can be explained at a micro-level and molecular level (Figure 21) [99]. At a micro-level, the particles of clay are plate-like and have more of a tendency to become firmly compact and fill in the spaces $[99,100]$. On the other hand, at a molecular level, crystalline clay in the presence of an alkaline solution is converted into silica and alumina superficially with non-bridged oxygen. After applying further pressure and heat, dissolution is promoted as the molecules come closer together along, with the phenomenon of the formation of bridged oxygen, hence promoting a geopolymerization reaction. 


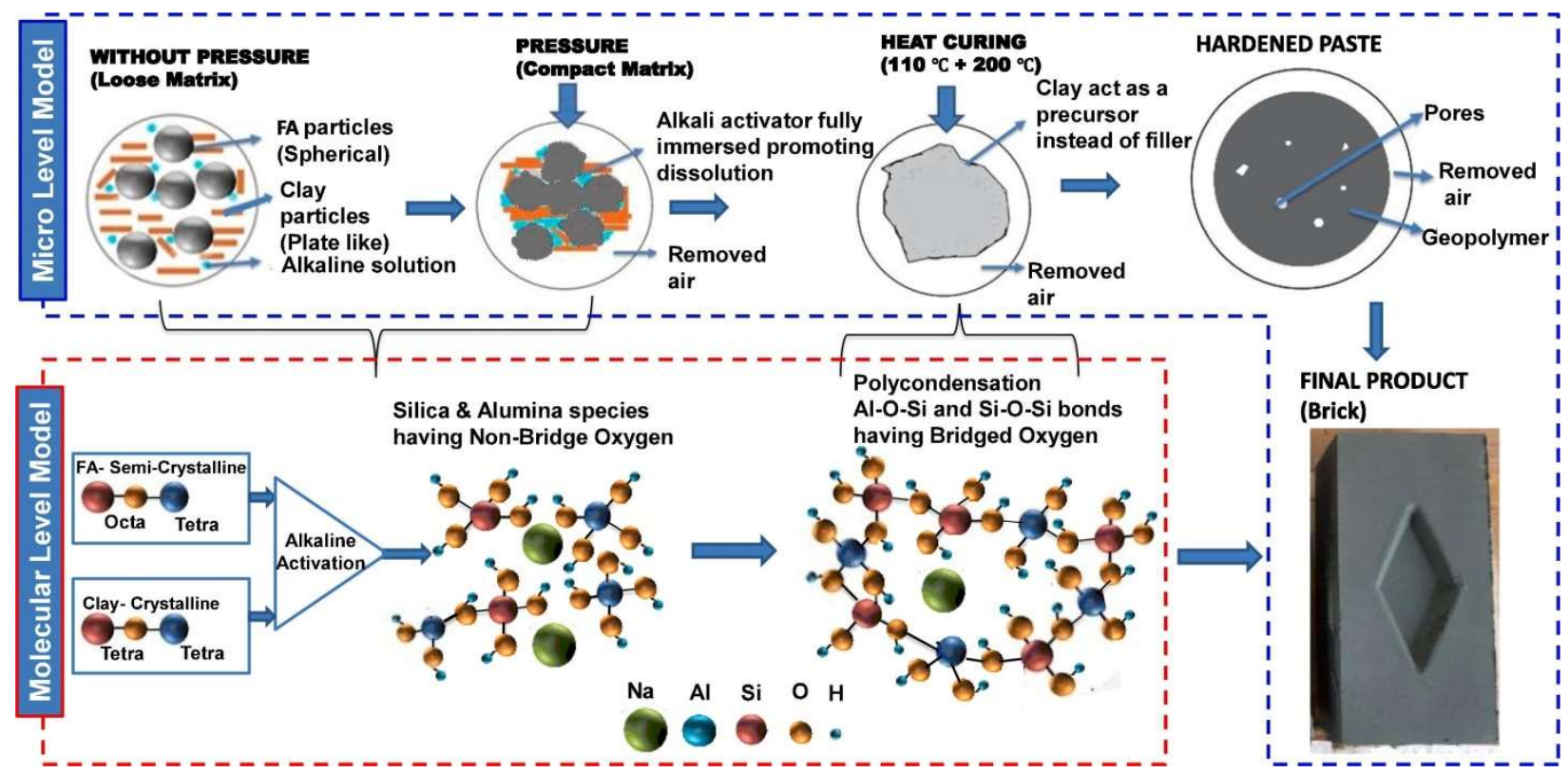

Figure 21. Strength gain mechanism at a micro and molecular level in bricks made from clay-based geopolymers [99].

\section{Conclusions}

This paper gives an overall view of the current state-of-the-art regarding the use of clays and clay minerals in the construction industry. A variety of clays and clay minerals are known. Under different treatments, clays can be used for different applications. Different types of clay minerals having different structural features available and can be used in the construction industry. When it is used as a supplementary cementitious material in OPC mortars and concrete, the compressive strength, durability, and sustainability of concrete are enhanced. Further using clay minerals, new types of binder such as LC ${ }^{3}$ have been made. When adding 40\% calcined kaolinite, higher strengths than OPC mortars were obtained after 7 days, irrespective of clay fineness. MK acts as a pozzolanic material forming C-A-S-H, AFm phases, and ettringite. Clays are also used for making geopolymer cement and concrete, and the concretes have better mechanical and durability properties and are equally timely and energy intensive. In the near future, $\mathrm{LC}^{\mathrm{s}}$ and geopolymer concrete may replace conventional cement and concrete. These binders are considered superior to conventional binders in many respects. Various types of bricks can also be made using clay. However, more research is needed on the applications of clay minerals in the construction industry.

Funding: This research received no external funding.

Data Availability Statement: Not applicable.

Conflicts of Interest: The author declares no conflict of interest.

\section{References}

1. Mousavi, S.S.; Bhojaraju, C.; Ouellet-Plamondon, C. Clay as a Sustainable Binder for Concrete-A Review. Constr. Mater. 2021, 1, 134-168. [CrossRef]

2. Damtoft, J.S.; Lukasik, J.; Herfort, D.; Sorrentino, D.; Gartner, E.M. Sustainable development and climate change initiatives. Cem. Concr. Res. 2008, 38, 115-127. [CrossRef]

3. Tironi, A.; Trezza, M.A.; Scian, A.N.; Irassar, E.F. Kaolinitic calcined clays: Factors affecting its performance as pozzolans. Constr Build. Mater. 2012, 28, 276-281. [CrossRef]

4. Khandelwal, S.; Rhee, K.Y. Evaluation of pozzolanic activity, heterogeneous nucleation, and microstructure of cement composites with modified bentonite clays. Constr. Build. Mater. 2022, 323, 126617. [CrossRef] 
5. Jaskulski, R.; Jóźwiak-Niedźwiedzka, D.; Yakymechko, Y. Calcined Clay as Supplementary Cementitious Material. Materials 2020, 13, 4734. [CrossRef]

6. Tuyan, M.; Andiç-Çakir, O.; Ramyar, K. Effect of alkali activator concentration and curing condition on strength and microstructure of waste clay brick powder-based geopolymer. Compos. B Eng. 2018, 135, 242-252. [CrossRef]

7. Longhi, M.A.; Rodríguez, E.D.; Walkley, B.; Zhang, Z.; Kirchheim, A.P. Metakaolin-based geopolymers: Relation between formulation, physicochemical properties and efflorescence formation. Compos. B Eng. 2020, 182, 107671. [CrossRef]

8. Panda, B.; Ruan, S.; Unluer, C.; Tan, M.J. Investigation of the properties of alkaliactivated slag mixes involving the use of nanoclay and nucleation seeds for 3D printing. Compos. B Eng. 2020, 186, 107826. [CrossRef]

9. Schulze, S.E.; Rickert, J. Suitability of natural calcined clays as supplementary cementitious material. Cem. Concr. Compos. 2019, 9, 92-97. [CrossRef]

10. Cardoso, T.C.; de Matos, P.R.; Py, L.; Longhi, M.; Cascudo, O.; Kirchheim, A.P. Ternary cements produced with non-calcined clay, limestone, and Portland clinker. J. Build. Eng. 2022, 45, 103437. [CrossRef]

11. Maier, M.; Sposito, R.; Beuntner, N.; Thienel, K. Particle characteristics of calcined clays and limestone and their impact on early hydration and sulfate demand of blended cement. Cem. Concr. Res. 2022, 154, 106736. [CrossRef]

12. Skibsted, J.; Snellings, R. Reactivity of supplementary cementitious materials (SCMs) in cement blends. Cem. Concr. Res. 2019, 124, 105799. [CrossRef]

13. Niu, X.-J.; Li, Q.-B.; Hu, Y.; Tan, Y.-S.; Liu, C.-F. Properties of cement-based materials incorporating nano-clay and calcined nano-clay: A review. Constr. Build. Mater. 2021, 284, 122820. [CrossRef]

14. Joshaghani, A.; Balapour, M.; Mashhadian, M.; Ozbakkaloglu, T. Effects of nanoTiO ${ }_{2}$, nano- $\mathrm{Al}_{2} \mathrm{O}_{3}$, and nano- $\mathrm{Fe}_{2} \mathrm{O}_{3}$ on rheology, mechanical and durability properties of self-consolidating concrete (SCC): An experimental study. Constr. Build. Mater. 2020, 245, 118444. [CrossRef]

15. Yamchelou, M.T.; Law, D.; Brkljac, R.; Gunasekara, C.; Li, J.; Patnaikuni, I. Geopolymer synthesis using low-grade clays. Constr. Build. Mater. 2021, 268, 121066. [CrossRef]

16. Singh, N.B.; Middendorf, B. Geopolymers as an Alternative to Portland cement: An Overview. Constr. Build. Mater. 2020, 237, 117455. [CrossRef]

17. Zhang, L.Y. Production of bricks from waste materials-A review. Constr. Build. Mater. 2013, 47, 643-655. [CrossRef]

18. Atyia, M.M.; Mahdy, M.G.; Elrahman, M.A. Production and properties of lightweight concrete incorporating recycled waste crushed clay bricks. Constr. Build. Mater. 2021, 304, 124655. [CrossRef]

19. Wang, S.; Gainey, L.; Baxter, D.; Wang, X.D.; Mackinnon, D.R.I.; Xi, Y.F. Thermal behaviours of clay mixtures during brick firing: A combined study of in-situ XRD, TGA and thermal dilatometry. Constr. Build. Mater. 2021, 299, 124319. [CrossRef]

20. Vasic, M.V.; Pezo, L.L.; Radojevic, Z. Optimization of adobe clay bricks based on the raw material properties (mathematical analysis). Constr. Build. Mater. 2020, 244, 118342. [CrossRef]

21. Pomakhina, E.; Deneele, D.; Gaillot, A.-C.; Paris, M.; Ouvrard, G. 29Si solid state NMR investigation of pozzolanic reaction occurring in lime-treated Ca-bentonite. Cem. Concr. Res. 2012, 42, 626-632. [CrossRef]

22. Wu, J.; Liu, L.; Deng, Y.; Zhang, G.; Zhou, A.; Xiao, H. Use of recycled gypsum in the cement-based stabilization of very soft clays and its micro-mechanism. J. Rock Mech. Geotech. Eng. 2021. [CrossRef]

23. Aramburo, C.H.; Pedrajas, C.; Talero, R. Portland Cements with High Content of Calcined Clay: Mechanical Strength Behaviour and Sulfate Durability. Materials 2020, 13, 4206. [CrossRef] [PubMed]

24. Alhawat, M.; Ashour, A.; Yıldırım, G.; Aldemir, A.; Sahmaran, M. Properties of geopolymer sourced from construction and demolition waste: A review. J. Build. Eng. 2022, 104104. [CrossRef]

25. Silva, G.; Castañeda, D.; Kim, S.; Castañeda, A.; Bertolotti, B.; Ortega-San-Martin, L.; Nakamatsu, J.; Aguilar, R. Analysis of the production conditions of geopolymer matrices from natural pozzolana and fired clay brick wastes. Construct. Build. Mater. 2019, 215, 633-643. [CrossRef]

26. Guggenheim, S.; Martin, R.T. Definition of clay and clay mineral: Joint report of the aipea nomenclature and cms nomenclature committees. Clays Clay Miner. 1995, 43, 255-256. [CrossRef]

27. Ni, J.; Lin, J.; Wei, R.; Yang, H.; Yang, Y. Does the Distribution of Polycyclic Aromatic Hydrocarbons in Soil Particle-Size Separates Affect Their Dissipation During Phytoremediation of Contaminated Soils? In Functions of Natural Organic Matter in Changing Environment; Springer: Dordrecht, The Netherlands, 2013; pp. 669-672.

28. Rao, K.S. Strategic use of soil in war operations: The role of dispersion flocculation thixtrophy and plasticity of clay. Def. Sci. J. 2013, 1, 192-204.

29. Kumari, N.; Mohan, C. Basics of Clay Minerals and their characteristic properties. Clay Clay Miner. 2021, 1-29. [CrossRef]

30. What Is Clay. Science Learning Hub. 2010. Available online: https://www.sciencelearn.org.nz/resources/1771-what-is-clay (accessed on 24 February 2022).

31. Augustyn, A. Clay, Encyclopedia Britanica. 2020. Available online: https://www.britannica.com/science/sand (accessed on 12 July 2021).

32. Velde, B. (Ed.) Composition and Mineralogy of Clay Minerals. In Origin and Mineralogy of Clays; Springer: Berlin/Heidelberg, Germany, 1995; pp. 8-42. [CrossRef]

33. Clay. Wikipedia. Available online: https:/ / en.wikipedia.org/wiki/Clay (accessed on 20 June 2020). 
34. Ma, Y.; Shi, C.; Lei, L.; Sha, S.; Zhou, B.; Liu, Y.; Xiao, Y. Research progress on polycarboxylate based superplasticizers with tolerance to clays-A review. Constr. Build. Mater. 2020, 255, 119386. [CrossRef]

35. Muhammed, N.S.; Olayiwola, T.; Elkatatny, S. A review on clay chemistry, characterization and shale inhibitors for water-based drilling fluids. J. Pet. Sci. Eng. 2021, 206, 109043. [CrossRef]

36. Awad, A.M.; Shaikh, S.M.; Jalab, R.; Gulied, M.H.; Nasser, M.S.; Benamor, A.; Adham, S. Adsorption of organic pollutants by natural and modified clays: A comprehensive review. Sep. Purif. Technol. 2019, 228, 115719. [CrossRef]

37. Del Mar Orta, M.; Martín, J.; Santos, J.L.; Aparicio, I.; Medina-Carrasco, S.; Alonso, E. Biopolymer-clay nanocomposites as novel and eco-friendly adsorbents for environmental remediation. Appl. Clay Sci. 2020, 198, 105838. [CrossRef]

38. Tournassat, C.; Bourg, I.C.; Steefel, C.I.; Bergaya, F. Surface Properties of Clay Minerals (Chapter-1). In Developments in Clay Science; Elsevier: Amsterdam, The Netherlands, 2015; Volume 6, pp. 5-31. [CrossRef]

39. Shubbar, A.A.; Sadique, M.; Kot, P.; Atherton, W. Future of clay-based construction materials-A review. Constr. Build. Mater. 2019, 210, 172-187. [CrossRef]

40. Le Quéré, C.; Moriarty, R.; Andrew, R.M.; Peters, G.P.; Ciais, P.; Friedlingstein, P.; Jones, S.D.; Sitch, S.; Tans, P.; Arneth, A.; et al. Global carbon budget 2014. Earth Syst. Sci. Data 2015, 7, 47-85. [CrossRef]

41. Wei, J.; Gencturk, B. Hydration of ternary Portland cement blends containing metakaolin and sodium bentonite. Cem. Concr. Res. 2019, 123, 105772. [CrossRef]

42. Gmür, R.; Thienel, K.C.; Beuntner, N. Influence of aging conditions upon the properties of calcined clay and its performance as supplementary cementitious material. Cem. Concr. Comp. 2016, 72, 114-124. [CrossRef]

43. Thienel, K.C.; Beuntner, N. Effects of Calcined Clay as Low Carbon Cementing Materials on the Properties of Concrete. In Concrete in the Low Carbon Era; Jones, M.R., Newlands, M.D., Csetenyi, L.J., Zheng, L., McCarthy, M.J., Dyer, T.D., Eds.; University of Dundee-Concrete Technology Unit: Dundee, UK, 2012; pp. 504-518.

44. Homayoonmehr, R.; Ramezanianpour, A.A.; Mirdarsoltany, M. Influence of metakaolin on fresh properties, mechanical properties and corrosion resistance of concrete and its sustainability issues: A review. J. Build. Eng. 2021, 44, 103011. [CrossRef]

45. Meddah, M.S.; Ismail, M.A.; El-Gamal, S.; Fitriani, H. Performances evaluation of binary concrete designed with silica fume and metakaolin. Construct. Build. Mater. 2018, 166, 400-412. [CrossRef]

46. Kostuch, J.; Walters, G.; Jones, T. High performance concretes incorporating metakaolin: A review. Concrete 1993, 2, $1799-1811$.

47. Cao, Y.; Wang, Y.; Zhang, Z.; Ma, Y.; Wang, H. Recent progress of utilization of activated kaolinitic clay in cementitious construction materials. Compos. Part B Eng. 2021, 211, 108636. [CrossRef]

48. Ouellet-Plamondon, C.; Scherb, S.; Köberl, M.; Thienel, K.-C. Acceleration of cement blended with calcined clays. Const. Build. Mater. 2020, 245, 118439. [CrossRef]

49. Scrivener, K.; Bazzoni, A.; Mota, B.; Rossen, J.E. Chapter 8 Electron microscopy. In A Practical Guide to Microstructural Analysis of Cementitious Materials; CRC Press LLC: Boca Raton, FL, USA, 2016; pp. 351-417.

50. Ilic, B.; Radonjanin, V.; Malešev, M.; Zdujic, M.; Mitrovic, A. Study on the addition effect of metakaolin and mechanically activated kaolin on cement strength and microstructure under different curing conditions. Constr. Build. Mater. 2017, 133, 243-252. [CrossRef]

51. Ilic, B.; Radonjanin, V.; Malešev, M.; Zdujic, M.; Mitrovic, A. Effects of mechanical and thermal activation on pozzolanic activity of kaolin containing mica. Appl. Clay Sci. 2016, 123, 173-181. [CrossRef]

52. Shanmugavadivu, V.; Karthikeyan, B.; Dhinakaran, G. Mechanical properties and micro-structure analysis of high-strength concrete with nano-metakaolin. Int. J. Appl. Eng. Res. 2014, 9, 4093-4106.

53. Zhan, P.-M.; He, Z.-H.; Ma, Z.-M.; Liang, C.-F.; Zhang, X.-X.; Abreham, A.A.; Shi, J.-Y. Utilization of nano-metakaolin in concrete: A. review. J. Build. Eng. 2020, 30, 101259. [CrossRef]

54. Shoukry, H.; Kotkata, M.F.; Abo-El-Enein, S.A.; Morsy, M.S.; Shebl, S.S. Enhanced physical, mechanical and microstructural properties of lightweight vermiculite cement composites modified with nano metakaolin. Construct. Build. Mater. 2016, 112, 276-283. [CrossRef]

55. Farzadnia, N.; Ali, A.A.A.; Demirboga, R.; Anwar, M.P. Effect of halloysite nanoclay on mechanical properties, thermal behavior and microstructure of cement mortars. Cem. Concr. Res. 2013, 48, 97-104. [CrossRef]

56. Reches, Y. Nanoparticles as concrete additives: Review and perspectives. Constr. Build. Mater. 2018, 175, 483-495. [CrossRef]

57. Givi, A.N.; Rashid, S.A.; Aziz, F.N.A. Salleh Mohamad Amran Mohd, Experimental investigation of the size effects of SiO 2 nano-particles on the mechanical properties of binary blended concrete. Compos. B Eng. 2010, 41, 673-677. [CrossRef]

58. Li, X.F.; Chen, H.Q. The influence of nano-kaolin to cement performance[C]. Appl. Mech. Mater. Trans. Tech. Publ. 2012, 174, 1208-1213. [CrossRef]

59. Tao, Y.; Gautam, B.P.; Pradhan, P.M.; Hu, C. Characterization and reactivity of Nepali clays as supplementary cementitious material. Case Stud. Constr. Mater. 2022, 16, e00947. [CrossRef]

60. Al-Akhras, N.M. Durability of metakaolin concrete to sulfate attack. Cem. Concr. Res. 2006, 36, 1727-1734. [CrossRef]

61. Courard, L.; Darimont, A.; Schouterden, M.; Ferauche, F.; Willem, X.; Degeimbre, R. Durability of mortars modified with metakaolin. Cem. Concr. Res. 2003, 33, 1473-1479. [CrossRef]

62. Güneyisi, E.; Gesoglu, M.; Karaboga, F.; Mermerda s, K. Corrosion behavior of reinforcing steel embedded in chloride contaminated concretes with and without metakaolin. Compos. Part B Eng. 2013, 45, 1288-1295. [CrossRef] 
63. Kelestemur, O.; Demirel, B. Effect of metakaolin on the corrosion resistance of structural lightweight concrete. Constr. Build. Mater. 2015, 81, 172-178. [CrossRef]

64. Ez-zaki, H.; Marangu, J.M.; Bellotto, M.; Dalconi, M.C.; Artioli, G.; Valentini, L. A Fresh View on Limestone Calcined Clay Cement $\left(\mathrm{LC}^{3}\right)$ Pastes. Materials 2021, 14, 3037. [CrossRef] [PubMed]

65. Hay, R.; Li, L.; Celik, K. Shrinkage, hydration, and strength development of limestone calcined clay cement (LC $\left.{ }^{3}\right)$ with different sulfation levels. Cem. Concr. Compos. 2022, 127, 104403. [CrossRef]

66. Ambroise, J.; Murat, M.; Pera, J. Hydration reaction and hardening of calcined clays and related minerals. V. Extension of the research and general conclusions. Cem. Concr. Res. 1985, 15, 261-268. [CrossRef]

67. Fernandez, R.; Martirena, F.; Scrivener, K.L. The origin of the pozzolanic activity of calcined clay minerals: A comparison between kaolinite, illite and montmorillonite. Cem. Concr. Res. 2011, 41, 113-122. [CrossRef]

68. He, C.; Osbaeck, B.; Makovicky, E. Pozzolanic reactions of six principal clay minerals: Activation, reactivity assessments and technological effects. Cem. Concr. Res. 1995, 25, 1691-1702. [CrossRef]

69. Hollanders, S.; Adriaens, R.; Skibsted, J.; Cizer, Ö.; Elsen, J. Pozzolanic reactivity of pure calcined clays. Appl. Clay Sci. 2016, 132, 552-560. [CrossRef]

70. Avet, F.; Scrivener, K. Investigation of the calcined kaolinite content on the hydration of Limestone Calcined Clay Cement (LC ${ }^{3}$ ) Cem. Concr. Res. 2018, 107, 124-135. [CrossRef]

71. Tironi, A.; Trezza, M.A.; Scian, A.N.; Irassar, E.F. Assessment of pozzolanic activity of different calcined clays. Cem. Concr. Compos. 2013, 37, 319-327. [CrossRef]

72. Silva, A.S.; Gameiro, A.; Grilo, J.; Veiga, R.; Velosa, A. Long-term behavior of lime-Metakaolin pastes at ambient temperature and humid curing condition. Appl. Clay Sci. 2014, 88-89, 49-55. [CrossRef]

73. Antoni, M.; Rossen, J.; Martirena, F.; Scrivener, K. Cement substitution by a combination of metakaolin and limestone. Cem. Concr. Res. 2012, 42, 1579-1589. [CrossRef]

74. Zunino, F.; Scrivener, K. Microstructural developments of limestone calcined clay cement (LC ${ }^{3}$ ) pastes after long-term ( 3 years) hydration. Cem. Concr. Res. 2022, 152, 106693. [CrossRef]

75. Nguyen, Q.D.; Afroz, S.; Zhang, Y.; Kim, T.; Li, W.; Caste, A. Autogenous and total shrinkage of limestone calcined clay cement $\left(\mathrm{LC}^{3}\right)$ concrete. Constr. Build. Mater. 2022, 314, 125720. [CrossRef]

76. Emmanuel, A.C.; Haldar, P.; Maity, S.; Bishnoi, S. Second pilot production of limestone calcined clay cement in India: The experience. Indian Concr. J. 2016, 90, 57-63.

77. Albidah, A.; Alghannam, M.; Abbas, H.; Almusallam, T.; Al-Salloum, Y. Characteristics of metakaolin-based geopolymer concrete for different mix design parameters. J. Mater. Res. Technol. 2021, 10, 84-98. [CrossRef]

78. Zhang, Z.H.; Zhu, H.J.; Zhou, C.H.; Wang, H. Geopolymer from kaolin in China: An overview. Appl. Clay Sci. 2016, 119, 31-41. [CrossRef]

79. Davidovits, J. Geopolymer Chemistry and Applications, 5th ed.; Institut Géopolymère: Saint-Quentin, France, 2008.

80. Duxson, P.; Provis, J.L.; Lukey, G.C.; van Deventer, J.S.J. The role of inorganic polymer technology in the development of 'green concrete'. Cem. Concr. Res. 2007, 37, 1590-1597. [CrossRef]

81. Castillo, H.; Collado, H.; Droguett, T.; Mario, V.; Garrido, P.; Palma, S. State of the art of geopolymers: A review. e-Polymers 2022, 22, 108-124. [CrossRef]

82. Masoule, M.S.T.; Bahrami, N.; Karimzadeh, M.; Mohasanati, B.; Shoaei, P.; Ameri, F.; Ozbakkaloglu, T. Lightweight geopolymer concrete: A critical review on the feasibility, mixture design, durability properties, and microstructure. Ceram. Int. 2022. [CrossRef]

83. Lahoti, M.; Wong, K.K.; Tan, K.H.; Yang, E.H. Effect of alkali cation type on strength endurance of fly ash geopolymers subject to high temperature exposure. Mater. Des. 2018, 154, 8-19. [CrossRef]

84. Chuah, S.; Duan, W.H.; Pan, Z.; Hunter, E.; Korayem, A.H.; Zhao, X.L.; Collins, F.; Sanjayan, J.G. The properties of fly ash based geopolymer mortars made with dune sand. Mater. Des. 2016, 92, 571-578. [CrossRef]

85. Nazari, A.; Bagheri, A.; Sanjayan, J.G.; Dao, M.; Mallawa, C.; Zannis, P.; Zumbo, S. Thermal shock reactions of Ordinary Portland cement and geopolymer concrete: Microstructural and mechanical investigation. Construct. Build. Mater. 2019, 196, 492-498. [CrossRef]

86. Liew, Y.; Heah, C.; Kamarudin, H. Structure and properties of clay-based geopolymer cements: A review. Prog. Mater. Sci. 2016, 83, 595-629. [CrossRef]

87. Davidovits, J. 30 years of successes and failures in geopolymer applications. Market trends and potential breakthroughs. In Geopolymer 2002 Conference; Geopolymer Institute: Saint-Quentin, Melbourne, Australia, 2002.

88. Davidovits, J. Geopolymers: Inorganic polymeric new materials. J. Mater. Educ. 1994, 16, 91-138. [CrossRef]

89. Davidovits, J. Geopolymers: Man-made rock geosynthesis and the resulting development of very early high strength cement. J. Mater. Educ. 1994, 16, 91-139.

90. Zhang, Y.S.; Sun, W.; Li, Z.J. Hydration process of potassium polysialate (K-PSDS) geopolymer cement. Adv. Cem. Res. 2005, 17, 23-28. [CrossRef]

91. Bing-Hui, M.; Zhu, H.; Xue-Min, C.; Yan, H.; Si-Yu, G. Effect of curing temperature on geopolymerization of metakaolin-based geopolymers. Appl. Clay Sci. 2014, 99, 144-148.

92. Mascarin, L.; Ez-Zaki, H.; Garbin, E.; Bediako, M.; Valentini, L. Mitigating the ecological footprint of alkali-activated calcined clays by waste marble addition. Cem. Concr. Compos. 2022, 127, 104382. [CrossRef] 
93. Almutairi, A.L.; Tayeh, B.A.; Adesina, A.; Isleem, H.F.; Zeyad, A.M. Potential applications of geopolymer concrete in construction: A review. Case Stud. Constr. Mater. 2021, 15, 200733. [CrossRef]

94. Rashid, K.; Haq, E.U.; Kamran, M.S.; Munir, N.; Shahid, A.; Hanif, I. Experimental and finite element analysis on thermal conductivity of burnt clay bricks reinforced with fibers. Constr. Build. Mater. 2019, 221, 190-199. [CrossRef]

95. Rauf, A.; Shakir, S.; Ncube, A.; Abd-ur-Rehman, H.M.; Janjua, A.K.; Khanum, S.; Khoja, A.H. Prospects towards sustainability: A comparative study to evaluate the environmental performance of brick making kilns in Pakistan. Environ. Impact Assess. Rev. 2022, 94, 106746. [CrossRef]

96. Fernandes, F.M. Clay bricks. In Long-Term Performance and Durability of Masonry Structures; Elsevier Ltd.: Amsterdam, The Netherlands, 2019; pp. 3-19. [CrossRef]

97. Wang, S.; Gainey, L.; Marinelli, J.; Deer, B.; Wang, X.; Mackinnon, I.D.; Xi, Y. Effects of vermiculite on in-situ thermal behaviour, microstructure, physical and mechanical properties of fired clay bricks. Constr. Build. Mater. 2022, 316, 125828. [CrossRef]

98. Guzlena, S.; Sakale, G.; Certoks, S.; Grase, L. Sand size particle amount influence on the full brick quality and technical properties. Constr. Build. Mater. 2019, 220, 102-109. [CrossRef]

99. Ahmad, M.; Rashid, K. Novel approach to synthesize clay-based geopolymer brick: Optimizing molding pressure and precursors' proportioning. Constr. Build. Mater. 2022, 322, 126472. [CrossRef]

100. Murmu, A.L.; Patel, A. Towards sustainable bricks production: An overview. Constr. Build. Mater. 2018, 165, 112-125. [CrossRef] 